\title{
El debate en torno al ornamento arquitectónico en la revista Arquitectura y Construcción (1897-1922)
}

Francisco Javier Otero Alia *

A medida que la historiografía de la arquitectura moderna ha ido abandonando la idea de una nítida escisión entre los estilos del pasado y el paradigma de la era contemporánea, ha desaparecido la creencia en un origen que antes se entedía como parte de un proceso lineal y una evolución positivista.

Resulta cada vez más evidente el hecho de que muchos de los patrones arquitectónicos de la modernidad han nacido de una forma dubitativa, incluso a través de la polémica, durante un periodo dilatado de investigaciones, ensayos y saltos atrás y adelante.

La convivencia de actitudes dispares acerca del futuro de la arquitectura caracteriza más esa época que la hegemonía o el carácter profético de alguna de ellas.

Como ejemplo de lo que decimos se puede considerar la pluralidad de posturas bien diferenciadas acerca de las formas, las funciones y los significados de la ornamentación arquitectónica, cuya coexistencia revela hasta qué punto constituye una simplificación excesiva del asunto querer exclusivizar el devenir de la arquitectura en la progresiva desornamentación de los edificios; máxime, si tenemos en cuenta la supervivencia de ideas calificadas como decimonónicas en fechas muy posteriores a la

\footnotetext{
* Escuelas Aplicadas de Artes y Oficios Artísticos.
} 
célebre proscripción loosiana del ornamento o a la erección de muchas de las obras maestras del Movimiento Moderno.

Las páginas de la revista Arquitectura y Construcción, escritas por arquitectos y dirigidas a los miembros de esta profesión entre 1897 y 1922, nos servirán para poner de manifiesto lo anteriormente expuesto.

Esta publicación no pretende ser un foro para controversia y tampoco renuncia nunca al intento de hacer prevalecer las opciones más próximas a su ideario arquitectónico, pero, a pesar de ello, recoge en su seno una variedad de posicionamientos sobre el tema suficientemente demostrativa del debate sobre la ornamentación arquitectónica.

\section{LA ORNAMENTACIÓN EN EL ECLECTICISMO}

Conviene recordar previamente las pautas que definen el buen arte edificatorio en aquellos años y los márgenes que en él tiene la ornamentación, las cuales son respaldadas por la mayoría de los teóricos y los críticos como modelo de la ortodoxia arquitectónica.

Como quiera que tales normas seguían emanando todavía en gran parte de los ambientes académicos, continuaban explicando lo ornamental a partir de su doble condición de accesoriedad y superficialidad, según correspondía a la herencia del clasicismo, aún presente.

Sin embargo, un criterio tan restrictivo no podía ser mantenido, a finales del siglo XIX, con la rigidez que a veces se pretendía. La imagen de la arquitectura había concedido ya al repertorio ornamental mucha más importancia de la que haría imaginar semejante filiación ideológica.

La escasa variedad compositiva y tipológica del academicismo y la necesidad de separar el arte arquitectónico del utilitarismo ingenieril - motivo éste que hacía poco aconsejable enfatizar en exceso la adecuación meramente funcional-, ayudan a que el ornamento consiga unas responsabilidades mayores que las que le corresponderian como mero auxiliar.

Son numerosísimas las ocasiones en las que los críticos de Arquitectura y Construcción evalúan la capacidad estética de un arquitecto o de una obra atendiendo a la decoración ${ }^{1}$, enjuician la "parte artística" ha-

'S. C., "Decoración de la farmacia del Dr. Boadella", Arquitectura y Construcción. Barcelona 1901, núm. 103, pág. 172. 


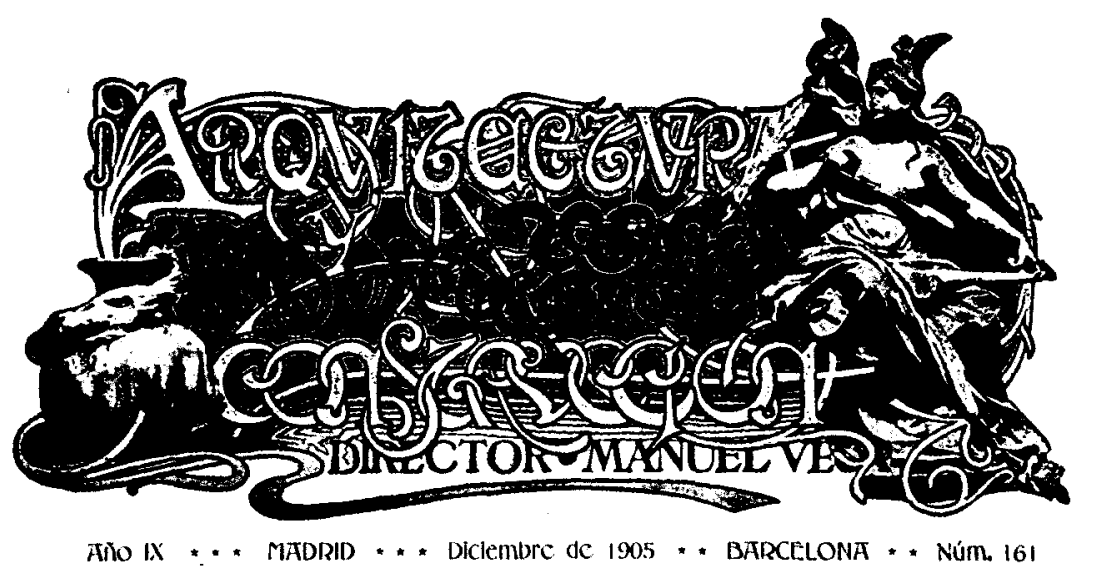

Fig. 1. Uno de los diseños gráficos que utilizó, para su cabecera la revista Arquitectura y Construcción.

ciendo repaso de ornamentos ${ }^{2} 0$, en términos similares, aproximan el concepto de belleza al de ornamentación, hasta casi confundirlos.

Resulta modélica la definición de la decoración como el «Factor esencialmente artístico", realizada por Cabello y Aso en 1905, quien proclama asi mismo la necesidad del ornamento para engalanar, enriquecer o aumentar la expresión, antes de decir que es «lo que el placer a la vida" ${ }^{3}$.

Por su parte, Manuel Aníbal Álvarez, en su discurso de recepción académica, aparecido también en Arquitectura y Construcción, admite que "La ornamentación es el complemento de toda obra arquitectónica, y para muchas personas la parte más artística” ${ }^{4}$.

Otros comentarios que, por su excepcionalidad, interesa destacar, son los expuestos por José Eugerio Ribera, ingeniero de profesión, en el Instituto de Ingenieros civiles de Madrid, los cuales se reproducen en

\footnotetext{
${ }^{2}$ Pujol, J., "La nueva Aduana de Barcelona", $A$ y $C$. 1902, núm. 120, pág. 204. (En adelante aparecerá $A$ y $C$ como abreviatura de Arquitectura y Construcción). 110.

${ }^{3}$ Cabello y Aso, L., "La belleza arquitectónica", $A$ y $C, 1905$, núm. 153, págs. 108 y

“ Aníbal Álvarez, M., “Lo que pudiera ser la arquitectura española contemporánea", $A$ y C, 1910, núm. 214, pág. 148.
} 


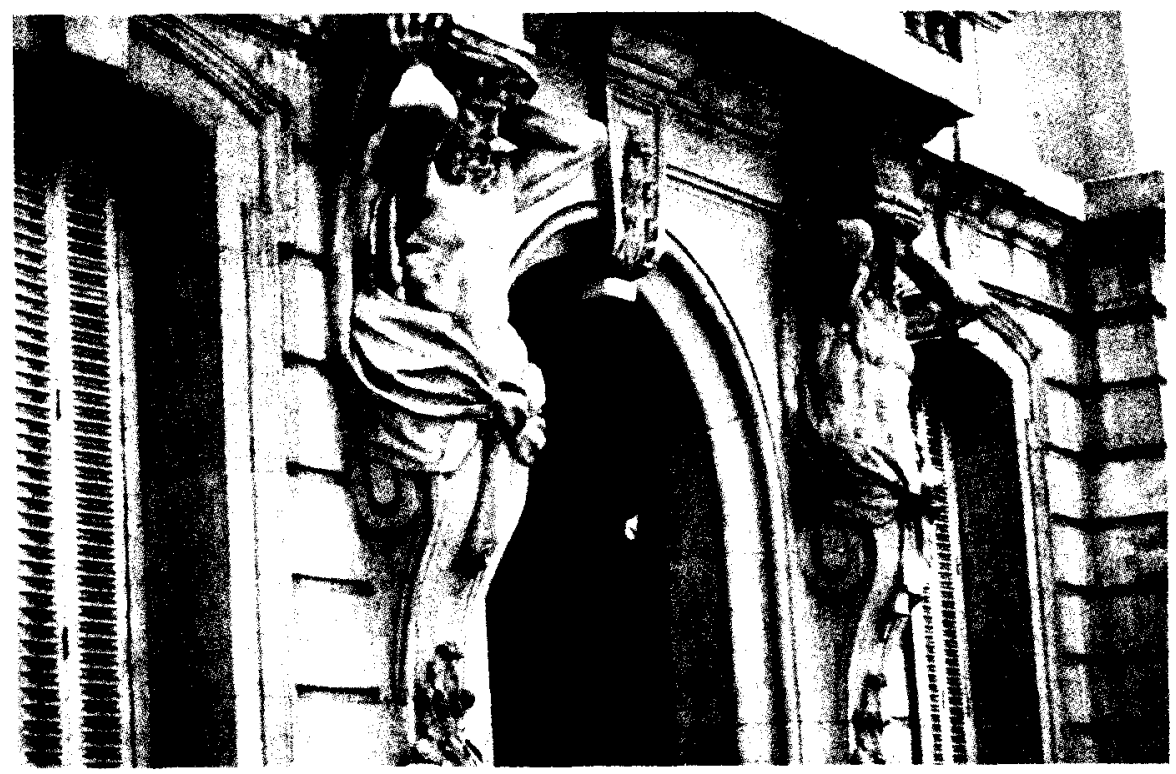

Fig. 2. Detalle de la fachada de la Real Academia de Medicina (1910), obra de Luis Maria Cabello Lapiedra, articulista habitual de Arquitectura y Construcción.

la citada revista en 1909. El mencionado ponente, insiste ante sus colegas en la necesidad de mejorar el aspecto de los puentes, para lo cual recomienda su ornamentación y aconseja que se recurra al asesoramiento de los arquitectos en esta tarea, al ser ellos más expertos en aportar tales «influencias artísticas» ${ }^{5}$.

Aparejada a la cuestión de la artisticidad, surge la de la riqueza, la segunda gran finalidad de la ornamentación. Luis María Cabello y Lapiedra decía que «... si la obra de arte resultase pobre..., puede y debe exornala con todos los elementos de que puede echar mano el Arquitecto" ' ${ }^{6}$, apología ornamental que no deja de sorprender en boca de uno de los más reputados defensores de la pureza arquitectónica académica.

El ambiguo significado del enriquecimiento, que igual podía coincidir con la representatividad de las instituciones públicas, con el prestigio social, la tradición nacional 0 , menos metafóricamente, con la prosperidad

'A y C, 1909, núm. 198, pág. 31.

"Cabello y Lapiedra, L. M."., "Desde Madrid", A y C, 1897, núm. 3, pág. 33. En términos muy semejantes sigue expresándose ANIBAL ÁlVAREZ, (op. cit., pág. 148) bastantes años más tarde. 
económica, llega a ser una exigencia en determinados encargos, claúsula cumplida generalmente a través de la ornamentación ${ }^{7}$.

Evidentemente, ni la artisticidad ni la riqueza del producto excusaban a los ojos de la crítica academicista un énfasis ornamental que atentase contra otras normas heredadas.

Para Torres Argullol es un «dislate inconmensurable» exclusivizar en lo ornamental la belleza arquitectónica ${ }^{8}$. En sentido semejante se expresa Cabello y Lapiedra al trazar una personal y sutil distinción entre la decoración -que identifica con la distribución y la proporción- y la ornamentación ${ }^{9}$.

Lo más frecuente es que se recuerde con frecuencia una serie de limitaciones a la fantasía ornamental, basadas principalmente en la pertinencia o no de un determinado motivo, según su aplicación prevista ${ }^{10}$, la adecuación de la forma al fondo, sin ocultar las estructuras ${ }^{11}$, el respeto al material ${ }^{12}$, etc.

La conclusión más lógica de la dialéctica que se establece entre estas restricciones y las alabanzas anteriores, no es otra que el reconocimiento implícito del valor de lo ornamental, al que explícitamente se intenta aún secundarizar, con la doble finalidad de no romper la tradición y evitar un temido libertinaje. Como veremos, estos autores intentan mantener un equilibrio entre la eliminación del ornato y su exageración, lo que les lleva a incurrir en contradicciones aparentes más de una vez.

Pero, además de las razones expuestas, hay otras causas que otorgan al ornamento un favor especial, al tiempo que suscitan su incremento y pluralidad.

La penetración de elementos ajenos al clasicismo alteró este código arquitectónico ya en fechas muy tempranas, incluso desde su interior. Ejemplos tan conocidos como los protorrománticos dibujos de Piranesi ${ }^{13}$

7 POLlEs, B., "Obras arquitectónicas de D. Francisco de Urcola", $A$ y $C, 1909$, núm. 204, pág. 194.

s Torres Argullol, J., “Asomos críticos”, A y C, 1901, núm. 99, pág. 103.

9 Cabello y lapiedra, L. Ma., op. cit., Ibidem.

10 Rodriguez CODOLA, M., "Arte e industria. Arte antiguo", $A$ y $C, 1903$, núm. 126, pág. 21.

"Cabello y Aso, L., op. cit., págs. 109-110 y Anieal; M., op. cit., Ibidem.

12 Agrasot, R., "La ley de la materia en la arquitectura", $A$ y $C, 1911$, núm. 222, págs. 10-14.

13 Rykwert, J., Los primeros modernos. Los arquitectos del siglo xVIII. Barcelona, Gustavo Gili, 1982, pág. 293. 
o las fantasías eclécticas de Percier y Fontaine ${ }^{14}$, evidencian este aspecto.

Cuando la necesidad de procurar ambientes pintorescos, capaces de estimular los sentidos y la imaginación, se hizo más perentoria, buscando la adecuación a un público más acostumbrado a leyendas y descripciones literarias que a la crítica arquitectónica, se inició una nueva consideración de repertorios ornamentales antes ignorados ${ }^{15}$.

La capacidad de evocación, completamente ajena, en principio a la intelectualidad de la belleza, pasó a ser un factor determinante. Lo pintoresco se hizo tan deseable como lo bello y, a veces, más popular ${ }^{16}$.

Así, a medida que la homogeneidad neoclásica, más aparente que real, iba cediendo ante el creciente subjetivismo, era más imposible mantener una valoración desigual del pasado. $Y$ como éste se había convertido en uno de los pilares de la doctrina arquitectónica, todos los estilos podian ahora apelar a tan alta instancia - la historia - para justificar su reaparición.

Ambos motivos, la evocación pintoresca y la libre disponibilidad de cualquier estilo como origen de inspiraciones, exigen que el ornamento represente un papel más activo, al demandar de la arquitectura una mayor elocuencia. La edificación debe exhibir su estilo, mostrar su "carácter", evocar una época o un ambiente.

Esto explica que, por ejemplo, Torres Argullol decida "exteriorizar el edificio por los medios del estilo ojival» ${ }^{17}$, dado su destino y su emplazamiento en una zona católica y catalana; o que Urioste asuma la combinación de las obras de Hontañón, Covarrubias y Egás para lograr que se rememore un supuesto estilo español ${ }^{18}$.

El ornamento presenta múltiples ventajas a la hora de conseguir la caracterización del estilo ${ }^{19}$, incluso cuando se utiliza de forma fragmen-

14 Honour, H., Neoclasicismo. Madrid, Xarait, 1982, pág. 199.

${ }^{15}$ Las conexiones entre neoclasicismo y pintoresquismo, así como la importancia de to evocativo quedan ampliamente tratadas en ColLINS, P., Los ideales de la arquitectura moderna, su evolución (1750-1950). Barcelona, Gustavo Gili, 1970 y en Hernando, J., Arquitectura en España, 1770-1900. Madrid, Cátedra, 1989.

16 Raquejo, T., El palacio encantado. La Alhambra en el arte britanico. Madrid, Taurus, 1990, págs. 30-32.

17 Torres, J., "Casa de curación para los heridos en el trabajo", A y C, 1988, núm. 34, pág. 226.

18 Urioste; J., “El Pabellón español en la Exposición de París de 1900", A y C, 1899, núm. 48, págs. 54-56.

19 Hernando, J., op. cit., pág. 173. 
taria o ahistórica, al ser su eficacia semántica muy apropiada para una comunicación más evidente de las sugerencias simbólicas y evocativas que otorgaban su razón de ser a las referencias estilisticas. El historicismo y el eclecticimos harian bues uso de esa potencialidad significativa, como siempre que se despierta la preocupación por la expresividad de la arquitectura ${ }^{20}$.

En definitiva, la quiebra de la exclusividad clasicista integra, junto a la necesaria demostración de la artisticidad y a la aportación de riqueza, los valores caracterizadores de la ornamentación, por lo que ésta se puede considerar, de hecho, como un elemento determinante del período y no como un mero auxiliar.

\section{TRADICIÓN Y RENOVACIÓN ORNAMENTAL}

\section{La necesidad de un nuevo estilo}

La aceptación progresiva del eclecticismo, que irá siendo admitido como un "período constituyente» ${ }^{21}$, "tránsito necesario" ${ }^{22}$ o comparado con el liberalismo - por oposición al absolutismo clasicista- ${ }^{23}$, no sosegó nunca el sentimiento de frustración que generaba la falta de un estilo unánimemente admirado como paradigma de la arquitectura moderna. Es más la preocupación crecía en forma proporcional al tiempo que pasaba sin que se encontrara una solución al problema.

En 1908, Arquitectura y construcción reproduce un artículo de la publicación francesa La Revue, en el que se habla con franqueza del tema, culpando del fracaso a "La manía del acopio erudito" y admirándose de como antes “los estilos se sucedian, naturalmente, en evolución...", normalidad que el autor atribuye a la absoluta indiferencia que el presente profesaba al pasado ${ }^{24}$.

Ciertamente, el peso de la historia, maestra irrefutable, no sólo dificultaba la solución del enigma, imponiendo la conciliación de pasado y

2o Jencks, CH., El lenguaje de la arquitectura posmoderna. Barcelona, Gustavo Gili, 1980 , pág. 25.

${ }^{21}$ Repullés, E.M., “Actualidades", $A$ y $C, 1903$, núm. 127, pág. 134.

22 Martorell, J., "La arquitectura moderna", $A$ y $C, 1908$, núm. 189, pág. 116.

${ }^{23}$ MartorelL, J., op. cit., pág. 115.

24 Jourdaln, F., "La arquitectura del mañana", $A$ y $C$, 1908, núm. 186, pág. 16. 


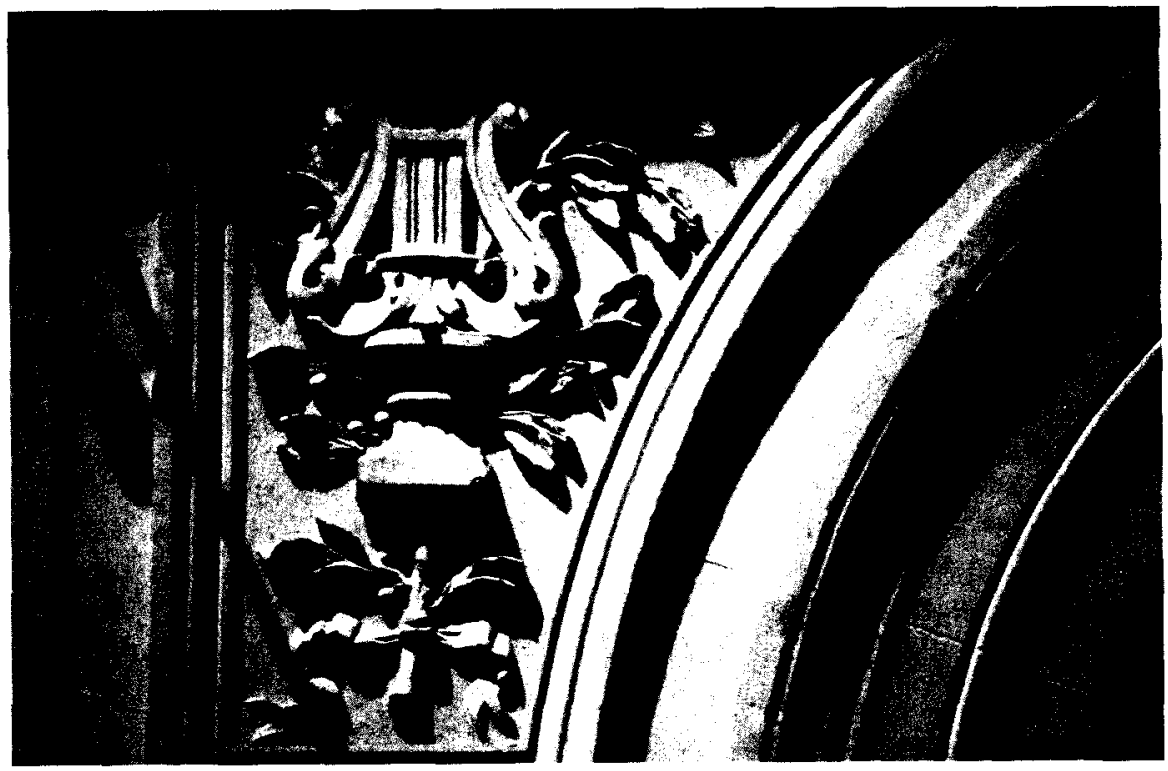

Fig. 3. El ornamento como símbolo de la función del edificio: Teatro de la Comedia, obra de Ortiz de Villajos, restaurada por López Sallaberry (1894 y 1897).

futuro, sino que generaba un complejo de inferioridad creciente, ante la facilidad de los antiguos para crear estilos nuevos para cada época, sin apenas preocuparse por ello.

Pero el mismo texto francés puede servirnos como ejemplo de la toma de conciencia que se está produciendo sobre la cuestión, lo que motivará que la dialéctica entre cambio y permanencia ${ }^{25}$ se manifieste a través de las diferentes alternativas que se presentan como posibles soluciones, surgidas unas como reformas respetuosas de lo institucionalizado y nacidas otras en oposición, más o menos intensa, con el modelo establecido.

Como obviamente, cada una de estas propuestas lleva consigo su propia teoria ornamental, la diversidad de actitudes en este apartado se incrementa de igual forma. Se abre asi un amplio abanico de posibilidades al respecto, desde la profusión hasta la negación, desde el naturalismo a la abstracción y desde el respeto a la historia a la ignorancia de la misma, incluyéndose, en cada caso, distintos estados intermedios.

${ }^{25}$ Sola-Morales, I., Eclecticismo y vanguardia. Barcelona, Gustavo Gili, 1980, pág. 104. 


\section{La perturbación modernista}

De todas las alternativas renovadoras que iban surgiendo en el terreno de la ornamentación arquitectónica, la más intranquilizadora para la óptica academicista era el modernismo.

Si hasta ahora la identificación, expresa o sugerida, del ornamento con la artisticidad habia garantizado un refugio ante la ingenierización, la entrada en escena de lenguajes ornamentales cada vez más inclasificables y antinormativos obligará a reordenar los límites en sentido contrario, intentando acotar la cuestión tanto por exceso como por defecto, sobre todo, al ser tomadas muchas propuestas modernistas como una especie de enemigo interior.

Sin embargo, aunque ambos -eclecticismo y modernismo- comparten una concepción semejante de la arquitectura, apoyada en la resolución individualista de problemas estéticos - la cual les impedirá configurar un proyecto arquitectónico contemporáneo-, sus deferencias tampoco permitirán ningún tipo de concesión mutua.

El protomodernismo que emana del conocido artículo de Domènech i Montaner "En busca de una arquitectura nacional» ${ }^{26}$ lo demuestra, ya que se adhiere expresamente al eclecticismo, sin renunciar por ello a un uso desprejuiciado y liberalizador del pasado, proponiendo una amalgama ornamental que no se podría entender desde el estatuto arquitectónico más ortodoxo.

El vocabulario que ahora se propone acepta la presencia de la historia, pero sus formas son reelaboradas, quedando incluso en simples sugerencias después de ser sometidas a ese proceso manipulador de los estilos, que a su vez se complica con elementos tomados de culturas antes ignoradas por el historicismo. Se añaden además las imágenes extraidas de la naturaleza, no sólo las estilizadas y pautadas geométricamente, sino también las nacidas de una imitación directa desacostumbrada ${ }^{27}$.

En el plano sintáctico se provoca una transformación igual o superior al léxico. Primero, se admiten asociaciones de elementos históricos antes inconcebibles, al aplicarse un sincretismo radical. Segundo, se supera la

26 DOMENECH I MONTANER, LI., “En busca de una arquitectura nacional», La Renaixensa, Any VIII, febrer 1878, págs. 149-160.

27 DOMENECH I MONTANER recuerda en $A$ y $C$ como buscaba y reproducia vegetales naturales ("Antonio M. " Gallisá", $A$ y $C, 1903$, núm. 51, págs. 164-171). 


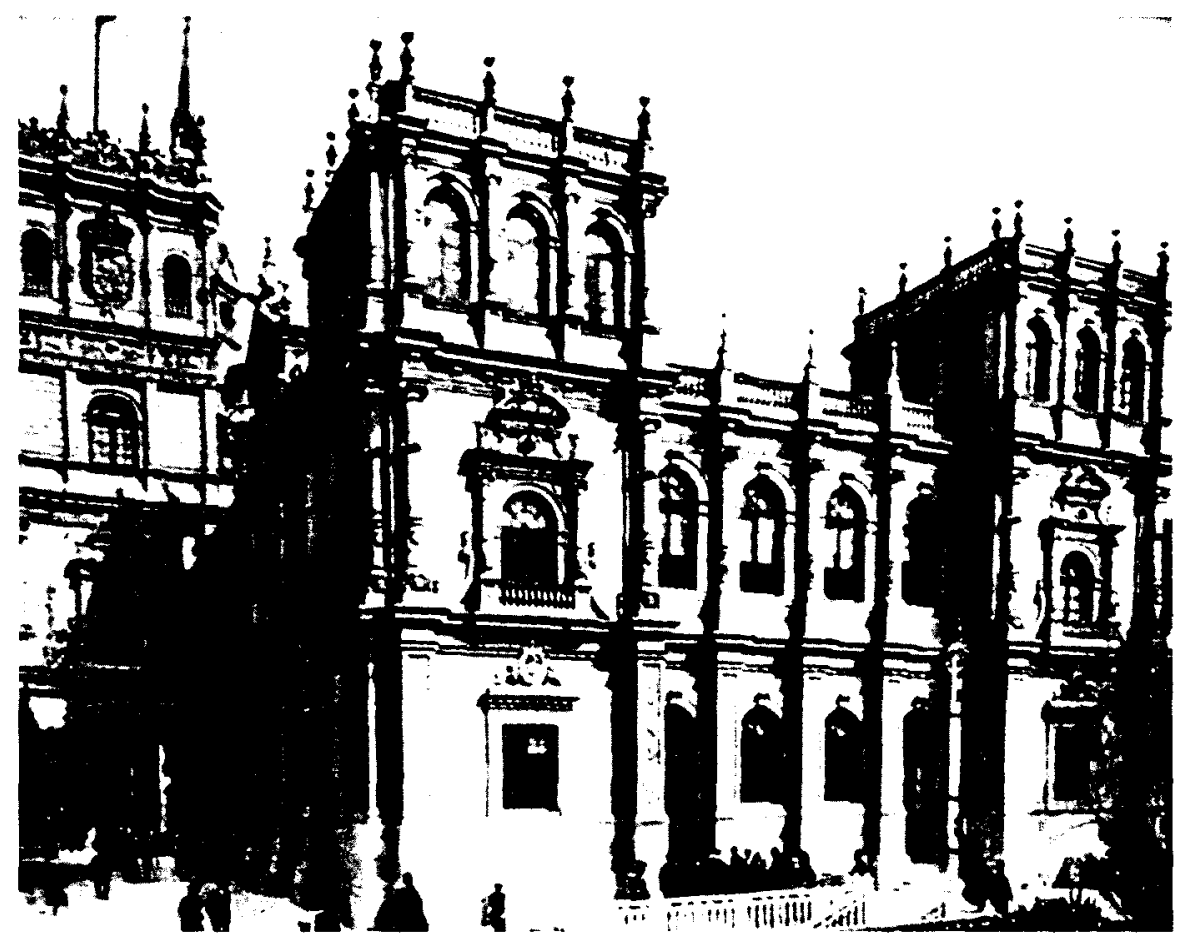

Fig. 4 José de Urioste: Pabellón Español en la Exposición de París de 1900.

accesoriedad como categoria propia del ornamento, actualizando cuantas técnicas decorativas puedan contribuir al logro de la estética deseada. Tercero, el ornamento refuerza el borrado de límites necesario para la creación de la plasticidad fluida y continua que caracteriza parte de la obra modernista ${ }^{28}$.

El ornamentalismo modernista puede llegar a constituir una tautologia, al ser proyectado sobre las superficies de unas obras que ya sobresalen por su potencia decorativa intrínseca, La teoría albertiana del edificio como ornamento de la calle y de la ciudad tiene, de este modo, una interpretación fundamentalista.

Contra semejante protagonismo ornamental reaccionan quienes defi-

${ }^{28}$ BoHIGAS, O., Reseña y catálogo de la arquitectura modernista. Barcelona, Lumen, 1983, pág. 211. 
nen la línea editorial de Arquitectura y construcción. Luis María Cabello no sólo reprueba esos "alardes de imaginación", sino que los compara con el "churriguerismo y barroquismo más desenfrenados" ${ }^{29}$, los estilos más aborrecidos por la Academia. Como él, otros muchos recuerdan que el ornato debería ser "el auxilio (y nada más que el auxilio)" de la buena arquitectura ${ }^{30}$ y que la belleza no se puede alcanzar "Trocando... en elemento principal al que deberia ser secundario y de detalle" ${ }^{31}$.

Tal exceso de ornamentación se asociaba al fachadismo, impulsado por unas excesivas ganas de fascinar el vulgo ${ }^{32}$, lo que provocaba además un encarecimiento innecesario de la obra.

Junto con la exageración cuantitativa se detectaban desaciertos cualitativos, tales como la mezcla de estilos: “...superposición y amalgama de elementos inadecuados..., como recogidos al azar en modelos diversos" ${ }^{33}$. Desde este punto de vista, Otto Wagner será calificado como un simple dibujante que "como tal ha combinado todos los elementos decorativos conocidos", por lo cual su obra "no responde a principios de Arte» ${ }^{34}$.

La imitación directa de la naturaleza provoca también vivas disputas. Dar forma de árbol a un pilar de piedra atenta, para Manuel Vega, contra el sentido común ${ }^{35}$ y arranca el máximo rechazo de Domènech y Estapà, quien lo califica de "extravio", mientras se pregunta «¿Qué relación puede guardar la forma de tronco de árbol... con la forma que debe afectar a una columna?" ${ }^{36}$, justo después de homologar el modernismo arquitectónico al religioso, considerado herético por Pio $\mathrm{X}$.

La censura del ornamento modernista servirá también como argumento para una descalificación general, precisando que tal decorativismo es más propio de una moda pasajera, incapaz de configurar un auténtico estilo. Esta es la causa de que el término "modernista" sea más usado

29 CABello, L. M. ${ }^{A}$, “Desde Madrid”, $A$ y $C, 1899$, núm. 55, pág. 166.

30 TORRES, J., "Las dos tendencias", $A$ y $C, 1899$, núm. 56, pág. 185.

3" VEGA, M., "La exposición de Turin", $A$ y $C, 1902$, núm. 123, pág. 302.

32 VEGA, M., "Actualidades", $A$ y $C, 1907$, núm. 176, págs. 66-68.

33 MORA, F., "La arquitectura contemporánea en Valencia", $A$ y $C, 1916$, núm. 291, pág. 221.

${ }^{34}$ CABello, L. M. ${ }^{a}$, "VIII Congreso Internacional de Arquitectos. Viena. 1908", $A$ y $C$, 1908, núm. 195, pág. 306. 176.

${ }^{35}$ VEGA, M., "La arquitectura moderna en Barcelona", $A$ y $C, 1905$, núm. 155, pág.

${ }^{36}$ DOMÉnECH I ESTAPA, J., “Modernismo arquitectónico", A y $C, 1912$, núm. 238, págs. 134-135 (Reprod. del discurso leido en la Real Academia de Ciencias y Artes de Barcelona). 


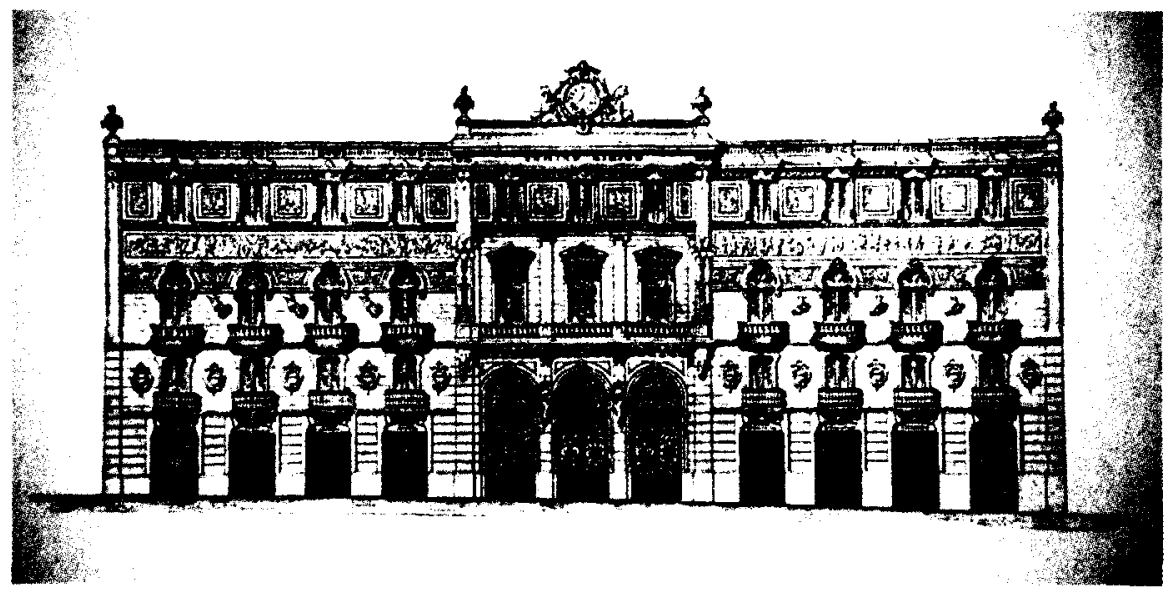

Fig. 5 J. Grases Riera: Nuevo Teatro Lírico de Madrid (posteriormente Liceo Francés), reproducido en Arquitectura y Construcción, 1902, pág. 234.

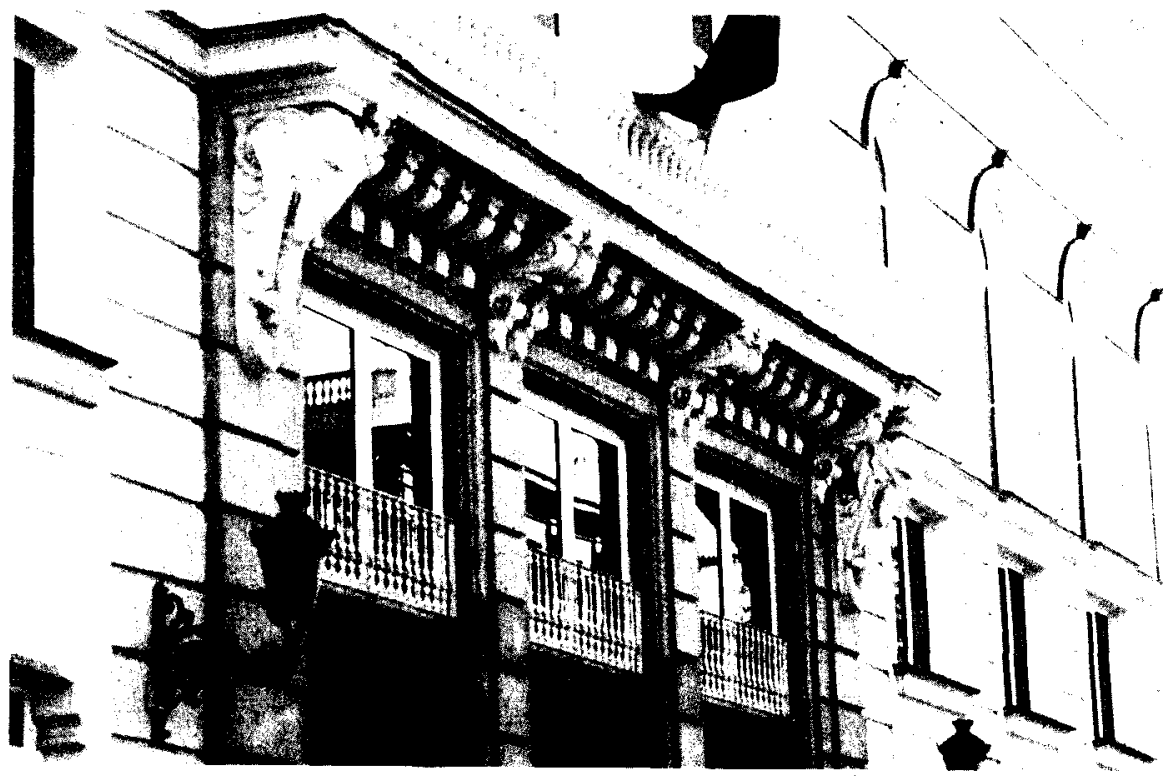

Fig. 6 Detalle del edificio de la ilustración anterior, con la ornamentación tipica de este arquitecto. 
por sus detractores que por sus defensores, ya que conllevaba ese sentido despectivo ${ }^{37}$.

Las opiniones en esta dirección son especialmente numerosas. Cabello habla de una moda caprichosa, extravagante y ridicula ${ }^{38}$, Torres dice que estas obras "pasarán sin dejar huella" ${ }^{39}$ y que "no es cosa que entren en ningún estilo" ${ }^{40}$, mientras Miguel Angel Trilles pide, en su discurso de recepción académica, que ojalá sea una "moda pasajera» esta "pesadilla" e "infierno" ".

Tan fuerte es la oposición que en el VI Congreso Internacional de Arquitectos, celebrado en Madrid, se propuso como tercera conclusión al tema cuarto la aceptación de que «El modern'style es la carencia de estilo...", anatema que sólo fue rectificado por la presión de arquitectos cercanos a él, como Puig i Cadafalch.

El hilo conductor entre modernismo, ornamentalismo exagerado, moda pasajera y carencia de estilo, era, frecuentemente, la consideración de que esos alardes ornamentales eran más propios de las artes aplicadas y no del arte puro ${ }^{43}$. Observar la revitalización de las artes decorativas y criticar el modernismo era todo uno, ya que lo que era admirable en estos objetos no podía influir en la más noble de las Bellas Artes.

Por si todo esto fuese poco, se acusaba también a las formas modernistas de extranjerismo, «... imitación ... mil veces más pecaminosa que la de las artes del Renacimiento o de la Edad Media..." ${ }^{44}$, por lo que el ornamentalisrno modernista se incluyó además en otro debate, el del regeneracionismo político y artístico ${ }^{45}$.

${ }^{37}$ Es perfectamente válido para la opinión de $A$ y $C$ lo que dice FreixA, M., al respecto en El modernismo en España. Madrid, Cátedra. 1986, pág. 19 y 22-23.

38 Cabello, L. M. a " "Desde Madrid", $A$ y $C, 1989$, n. 51, pág. 101. En los mismos términos se expresa ańos después ("VIII Congreso...", pág. 304).

39 TORRES, J., op. cit., pág. 186.

4 Torres, J., "Asomos críticos", A y C, 1901, n. 95, pág. 44.

41 Trilles, M. A., "El modernismo en la escultura”, $A$ y $C, 1913$, n. 250, pág. 98-104. pág. 112.

42 "VI Congreso Internacional de Arquitectos. Madrid, 1904", A y C, 1904, núm. 141,

${ }^{43}$ La aceptación del ornamentalismo modernista en las artes aplicadas y su censura en la arquitectura aparece, por ejemplo, en: VEGA, M., "La consigna revolucionaria", $A$ y $C$, 1902, núm. 114, pág. 14; Cabello, J. M. ", "VIII Congreso...", pág. 304; DOMÉnECH I EstaPA, op. cit., pág. 140 y también es tratado en "VI Congreso...", pág. 106. 362.

44 "Ante la obra "Hierros artísticos" de D. Luis Labarta", A y C, 1901, núm. 113, pág.

${ }_{45}$ De las complejas relaciones entre noventayochismo, modernismo y novecentismo se han ocupado, entre otros BOHIGAS, O. op. cit., págs. 33-42, SOlA-MORAlES, I., op. cit., págs. 80-89 y Freixa, M., op. cit., págs. 26-28. 
Vega, Repullés, Domènech i Estapà y, lógicamente, Rucabado, son algunos de los que más repudian la incorporación de imágenes "exóticas" en la arquitectura, lo que impedirá, según ellos, una auténtica originalidad ${ }^{46}$.

A la par que se suceden en aluvión estas críticas, irán encontrando acomodo en Arquitectura y construcción otras opiniones más flexibles. Un primer grupo de alabanzas son aquellas que admiten determinados ejemplos de renovación ornamental aunque intentan limitar su alcance. Estos elogios son rápidamente matizados, dejándolos reducidos a la categoria de ejemplos aislados, cuya repetición no es en absoluto aconsejable. Buenaventura Pollés los repite varias veces, como queriendo hacer constar que nunca formarán un estilo, y dice, verbigracia, que estas obras «son dignas de admitación ..., pero ninguna ... debe ser objeto de imitación” ${ }^{47}$.

Un segundo conjunto valorizador del modernismo, aunque igualmente un tanto matizado, va unido a las obras de los arquitectos cuya reputación indiscutible hace que el critico refrene sus palabras y se muestre más piadoso. También en este caso los aplausos recaen en quienes se emplean de manera menos radical en el tratamiento de la ornamentación.

Esta es una de las razones que hacen que sea Enric Sagnier el arquitecto más respetado, en quien se ve "un sentido modernismo sin tocar jamás en los linderos de la exageración" ${ }^{48}$, evitando caer en el habitual "pecado artístico" ${ }^{49}$ que se identifica con el énfasis ornamental. Seguramente el eclecticismo de Sagnier y su facilidad para recordar cuando es necesario un lenguaje ornamental tradicional, colaboran igualmente en el hecho de que nadie reciba más premios que él en los concursos anuales del Ayuntamiento ${ }^{50}$.

Tras Sagnier, es Puig i Cadafalch el más cómodamente asimilado, al no desprenderse nunca su ornamentalismo de una contextualización

46 VeGA, M., "Regeneración artistica", $A$ y C, 1901, núm. 111, pág. 310. Repullés, E. M., "Actualidades", $A$ y $C, 1902$, núm. 131, pág. 163. VEGA, M., "La arquitectura moderna en Barcelona»..., pág. 170. DOMĖNECH I ESTAPA, op. cit., pág. 143.

47 Pollés, B., "Arquitectura extranjera", A y $C$, 1901, núm. 109, pág. 268. Palabras semejantes dice Pollés en «El museo Horniman de Londres», $A$ y $C$, 1902, núm. 114, pág. 30.

48 Polles, B., "Finca de recreo llamada "El pinar" en la ladera del Tibidabo", $A$ y $C$, 1905, núm. 150, pág. 4.

"Pujol, J., "Arte e industria", $A$ y $C, 1902$, n. 116, pág. 78.

so Los éxitos de Sagnier y la historia de estos concursos pueden seguirse puntualmente a través del Anuario de la Asociación de Arquitectos de Cataluña. Barcelona 1899-1928. También puede verse BoHIGAS, O., "Los premios de Arquitectura y Decoración. Los premios FAD y los antiguos Premios del Ayuntamiento", Revista, Barcelona, junio 1959. 


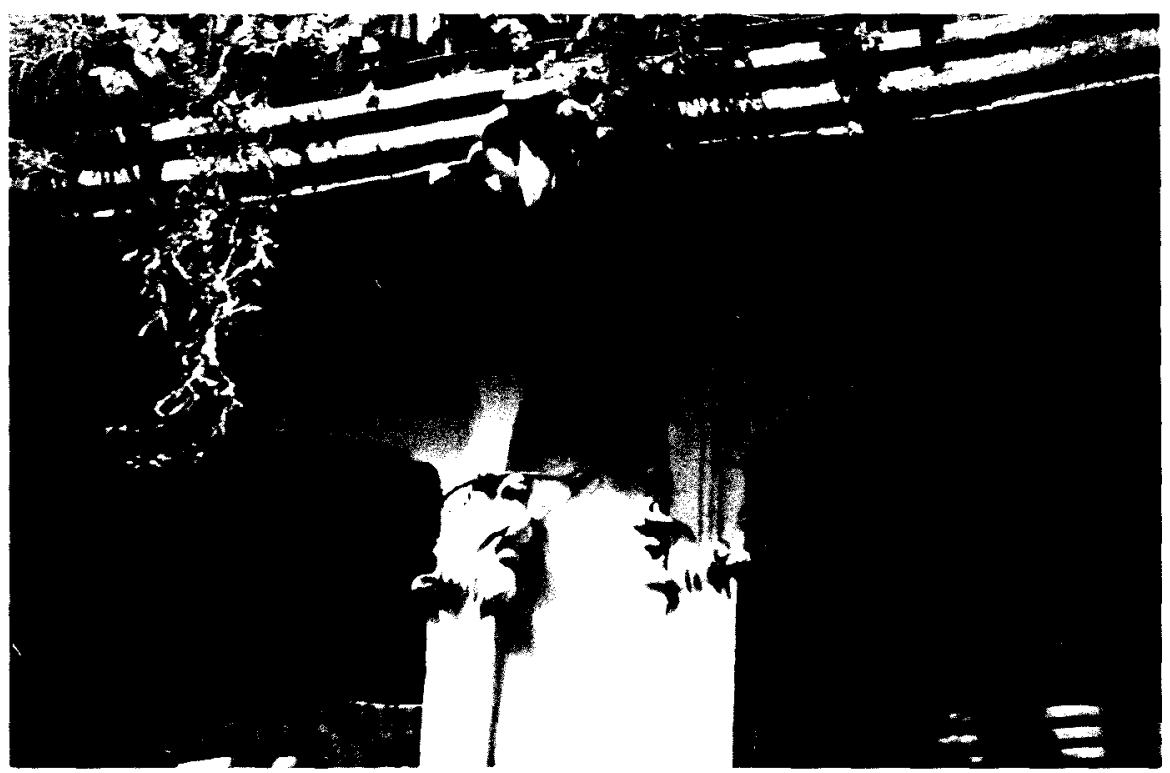

Fig. 7 Plasticidad de la ornamentación fitomónfica modernista: Casa Pérez Villamil. Eduardo Reynals (1906). Edificio comentado en Arquitectura y Construcción, 1908, págs. 292-294.

historicista, especialmente gótica. Por ello, sus obras son reiteradamente elogiadas $^{51}$.

Domènech i Montaner también es separado del mal modernismo, pero en los comentarios de sus obras empezamos a ver ya un uso mayor de ese doble lenguaje. Así, mientras se ensalza el empleo que hace del ladrillo, sus volúmenes claros y el uso de la simetría, se ponen reparos a "la profusa multiplicación de otros elementos secundarios" ${ }^{52}$, es decir, su ornamentación hace a sus edificios menos digeribles.

Si el racionalismo domenechiano aumentaba el grado de aceptación de su arquitectura, el expresionismo gaudinista será siempre enjuiciado desde la óptica de la anormalidad del genio aisiado, a lo que se une la censura de cualquier intento de extensión de tan incalificable arquitectura.

51 Pollés, B., “Arquitectura española contemporánea", $A$ y $C, 1901$, núm. 97, pág. 7 y "Nuevo Hotel Términus en Barcelona", $A$ y $C$, 1903. núm. 132, págs. 200-201. (s.n.): "Arquitectura española contemporánea", $A$ y $C$, 1901, núm. 111, págs. 303-306.

${ }^{52}$ VeGA M., “El edificio del Orfeó Catalá», A y C, 1908, pág. 70. 
Sólo la "Sagrada Familia" merece loas unánimes, que incluyen también a la ornamentación, sin que en este caso se despierten las protestas ni por su abundancia, ni por su naturalismo, ni por ninguna otra razón ${ }^{53}$. Pero más que la propia obra, son su significación religiosa -como ejemplo de una religiosidad incuestionable - y su importancia urbana -emblema elocuente de la pujanza de la ciudad-, los causantes de esa admiración y del orgullo con que se traducen las admirativas críticas francesas, motivadas por la exposición de los planos y la maqueta del Templo en París ${ }^{54}$.

Pero el resto de la obra gaudiniana es casi ignorada, al igual que ocurre con cualquier otro arquitecto modernista. Al reducir así el magisterio de estos creadores y al ahondar aún más el individualismo de Gaudi, se evitaba cualquier posible aprobación de la contaminación modernista ${ }^{55}$.

El tercer grupo de opiniones favorables al modernismo y su ornamentación es el más interesante, puesto que, al declarse abiertamente partidarias de ambos, permite observar una polémica real.

Victor Masriera es el primero en alzar seriamente su voz en contra de los antimodernistas ${ }^{56}$. Defensor de la ornamentación y de los decoradores, considera que desde el Renacimiento se les ha tiranizado, obligándoles a la copia de los estilos pasados, causa por la cual "se hicieron revolucionarios" ${ }^{57}$.

Esta revolución necesaria transformará la ornamentación a partir del gusto por lo japonés ("con los japoneses se aliaron los revolucionarios") y por la imitación de la naturaleza («nos proporcionará siempre formas nuevas") ${ }^{58}$.

Jeroni Martorel el autor del cuerpo teórico más amplio y profundo en favor del modernismo, expuesto en cinco entregas ${ }^{59}$ en 1908. También

53 Sellés, S., “El templo de la Sagrada Familia», A y C, 1908, núm. 186, págs. 4-11. VEGA, M., "La arquitectura moderna en Barcelona"..., pág. 177 y “Actualidades", $A$ y $C$, 1909 , núm. 208, págs. 322-324.

${ }_{54}$ El arquitecto Gaudí en el Salón de la Nationale de París", $A$ y $C, 1910$, núm. 217, págs. 240-248.

${ }_{55}$ VEGA, M., "Casa de alquiler en la calle de Caspe», A y $C, 1900$, núm. 81, pág. 200 y DOMENECH I EstAPA, J., op. cit., págs. 144-145.

${ }^{56}$ MAShierA, V., “Carta abierta a D. R. Balsa de la Vega", A y C, 1904, núm. 146, págs. 264-266.

${ }^{57}$ Masriera, V., op. cit., pág. 266.

58 Ibidem.

59 MARTORELL, J., "La arquitectura moderna», $A$ y $C$, 1910, núm. 188, págs. 79-90; núm. 189, págs. 110-118; núm. 190, págs. 140-148; núm. 192, págs. 205-212 y núm. 194, págs. 268-274. 


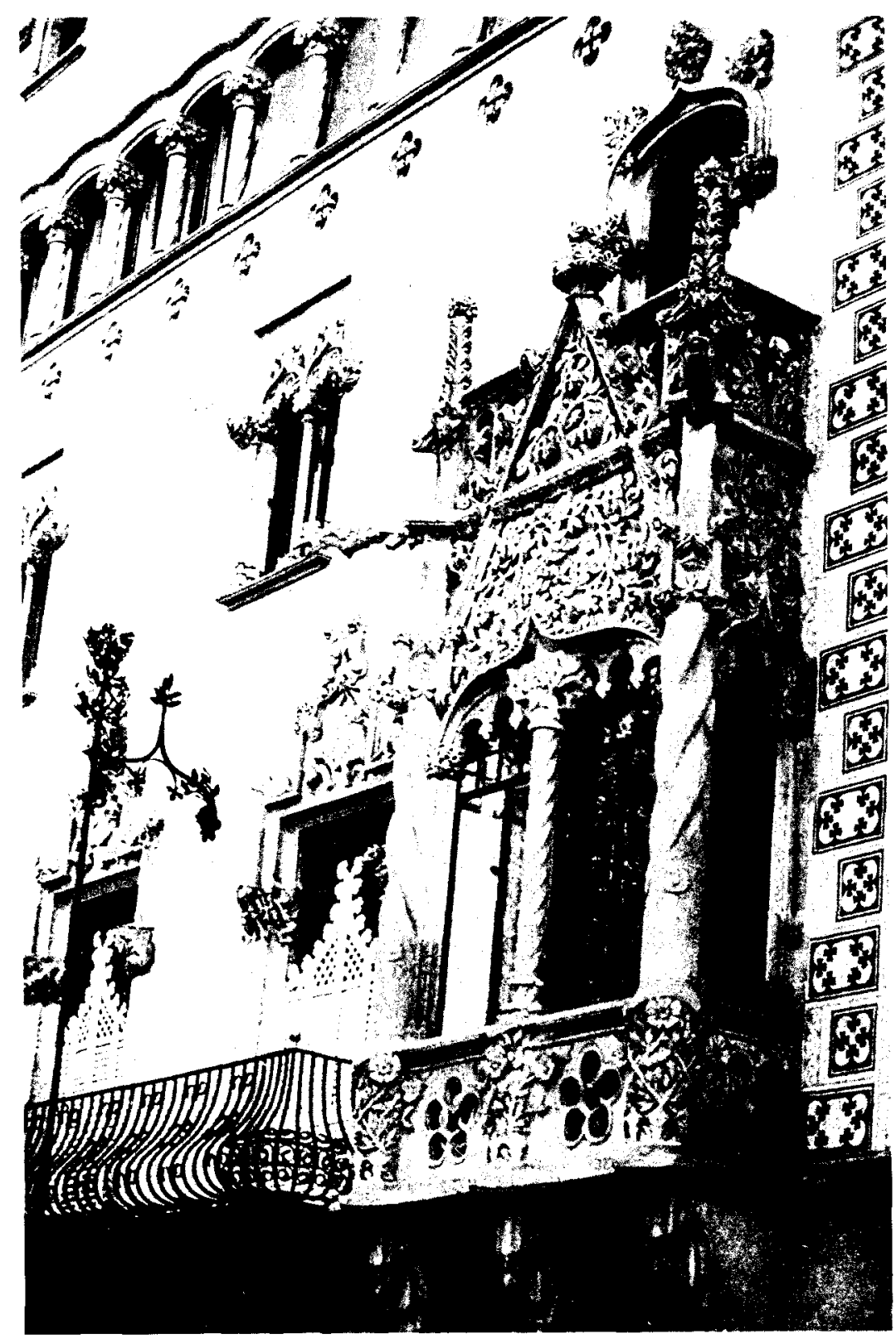

Fig. 8 Puig i Cadafalch: Casa Amatller, una de las construcciones modernistas que ilustraron Arquitectura y Construcción, en el año 1901. 
en este caso hace repaso de las teorías arquitectónicas dominantes y su forma de entender la ornamentación.

Defensor de Ruskin y Viollet-le-Duc, su paradigma es una arquitectura sin exageraciones decorativas, pero en la que el ornamento contribuye poderosamente a la renovación y modernización ansiadas. Por ello, alaba la originalidad de Wagner, al crear nuevos ornatos por simbiosis de formas anteriores, y aún más a Olbrich por el naturalismo de sus rosas y por el singular empleo que hace de estos adornos ${ }^{60}$. Interesante es también su defensa de la unión de racionalismo y ornamentación que hacen los americanos Richardson y Sullivan ${ }^{61}$.

Salvador Sellés hace, en 1910, la última gran defensa del ornamentalismo modernista ${ }^{62}$. Abordando el tema de la verdad en el arte, efectúa una igualación de este término al de originalidad, la cual, a su vez, hace depender poderosamente de la ornamentación.

La decoración árabe, la flora y la fauna renacentistas, las gárgolas góticas o el empleo de cariátides y atlantes, demostrarian, en su opinión, que la verdad artistica es siempre subjetiva y que la fantasía ornamental “no sólo es tolerable, sino exigible» ${ }^{63}$, con tal que favorezca la obra. Por lo tanto, encuentra plenamente justificada la originalidad decorativa como medio para renovar la arquitectura.

\section{Persistencia del academicismo y "Estilo moderno"}

Como demuestra el cruce de las opiniones anteriores, la implantación del modernismo, ni siquiera en sus momentos más álgidos, llegó a anular la concepción de la arquitectura del eclecticismo académico.

La buena salud de este modelo arquitectónico es aún más fehaciente a través de los aplausos que reciben, por ejemplo, los pabellones historicistas de la Exposición de $1900^{64}$, el uso del clasicismo como emblema

60 Martorell, J., op. cit., núm. 190, págs. 142-146.

${ }^{61}$ Martorell, J., op. cit., núm. 194, pág. 271. 2-13.

62 Sellés, S., "El modernismo y la verdad en el arte", $A$ y $C, 1910$, núm. 210, págs.

63 Selles, S., op. cit., pág. 12.

64 VARGAS, J. de, "Los arquitectos en la Exposición de 1900", A y C, 1899, núm. 61. pág. 261. 
de la alta burguesía ${ }^{65}$ o el neogótico como símbolo del valencianismo ${ }^{66}$, sobre todo porque en muchos de estos casos se le considera expresamente superior a su competidor modernista.

La longevidad de esos pensamientos les permite proclamar su victoria frente al modernismo, reducido ya a un historicismo más, en lugar de ser una alternativa auténtica.

En 1917 se congratula la critica de como se han abandonado "aquellas prolijidades y exhuberancias" ${ }^{67}$, y se recuerda, en 1919 , la obligación de ornamentar los nuevos edificios de Correos de acuerdo a los estilos tradicionales, admirándose el comentarista de aquellos en los que esa premisa se ha cumplido más evidentemente ${ }^{68}$.

La necesidad de homogeneizar la imagen de los edificios más representativos mediante el uso de lenguajes universalizadores explica sufi-

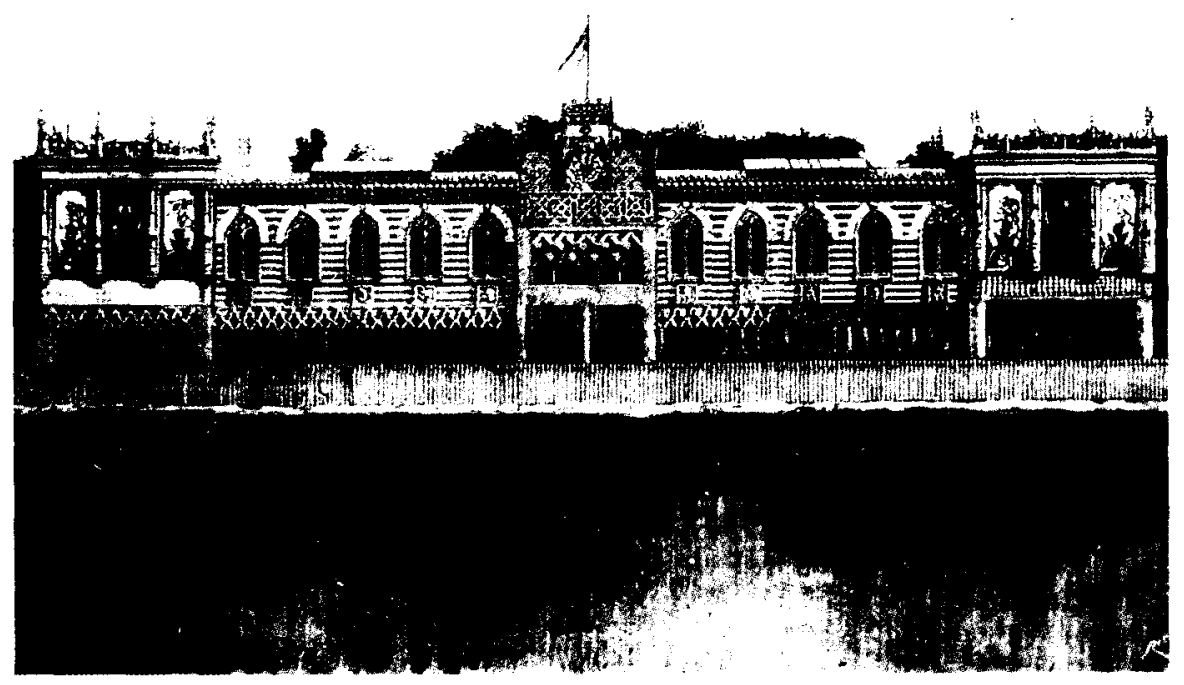

Fig. 9 Arturo Mélida: Pabellón Español para la Exposición de Paris de 1889.

65 "Casa palacio de D. Julio Castañedo", A y C, 1908, núm. 194, pág. 264.

${ }^{66}$ POLLES, B., "El Palacio Municipal de la Exposición de Valencia", A y $C$, 1910, núm. 213, págs. $100-108$.

67 "Arquitectura española contemporánea", A y C, 1917, pág. 187.

6e Cabello, L. M. ${ }^{a}$., "Los nuevos edificios para Correos y Telégrafos", $A$ y $C, 1919$, págs. 81-84. 


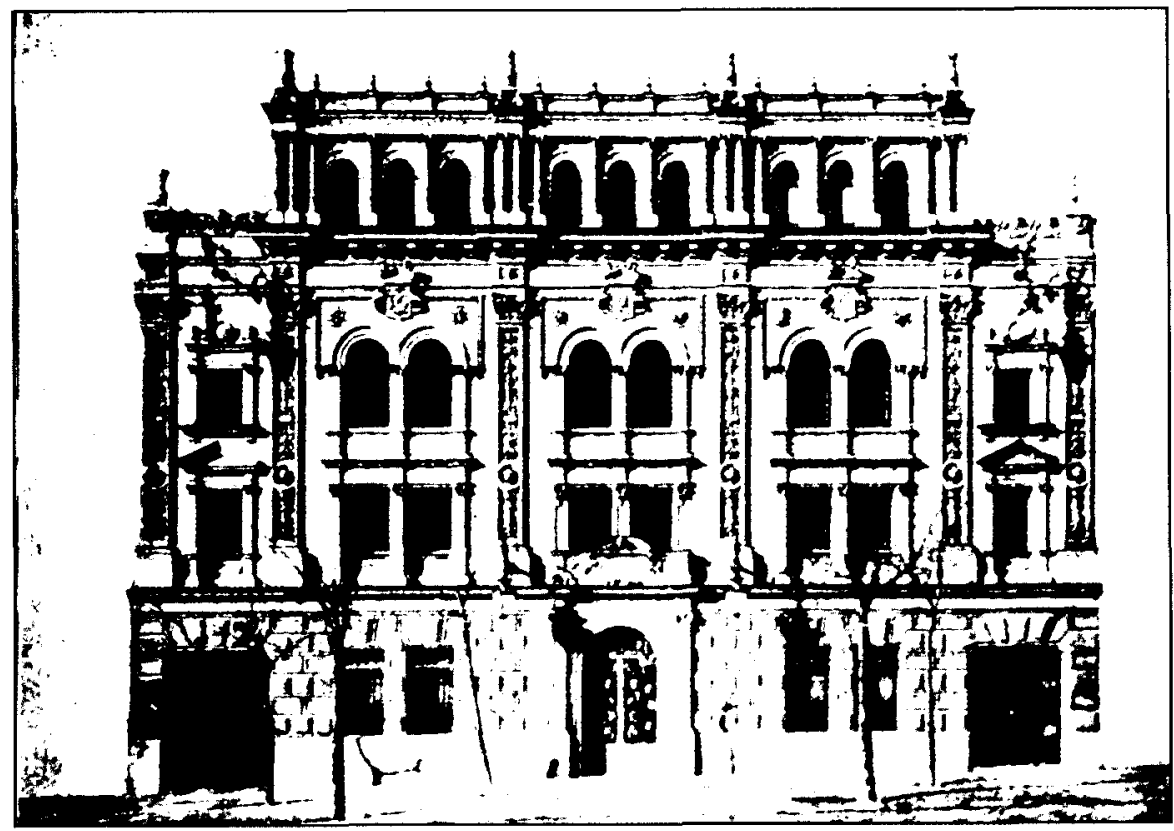

Fig. 10. Un ejemplo de "Estilo Moderno" para Arquitectura y construcción: Edificio de la revista Blanco y Negro, de J. López Sallaberry (año 1899, pág. 103).

cientemente el rápido abandono del ornamentalismo modernista, incluso en las regiones de su origen y máxima implantación ${ }^{69}$, realimentando también la permanencia de modelos arquitectónicos pocas veces considerados como propios del siglo $\mathrm{xx}$.

Sin embargo, la exigencia de reformar la arquitectura tampoco es ignorada por los teóricos más conservacionistas, por lo que se intentará proponer una alternativa desde dentro del sistema, conciliando los progresos más incuestionables con la salvaguarda del carácter artístico.

Un ejemplo temprano del afán de renovación interna es el propuesto por Arturo de Mélida y Alinari en su discurso de recepción en la Academia de San Fernando, reproducido en parte en Arquitectura $y$

* Aunque la suplantación del modernismo por el novecentismo es considerada por Bohigas, O. (Reseña y catálogo..., pág. 115) como algo incomprensible y reaccionario, Sola- Morales, I. da una explicación lógica del asunto (op. cit., pág. 83). 


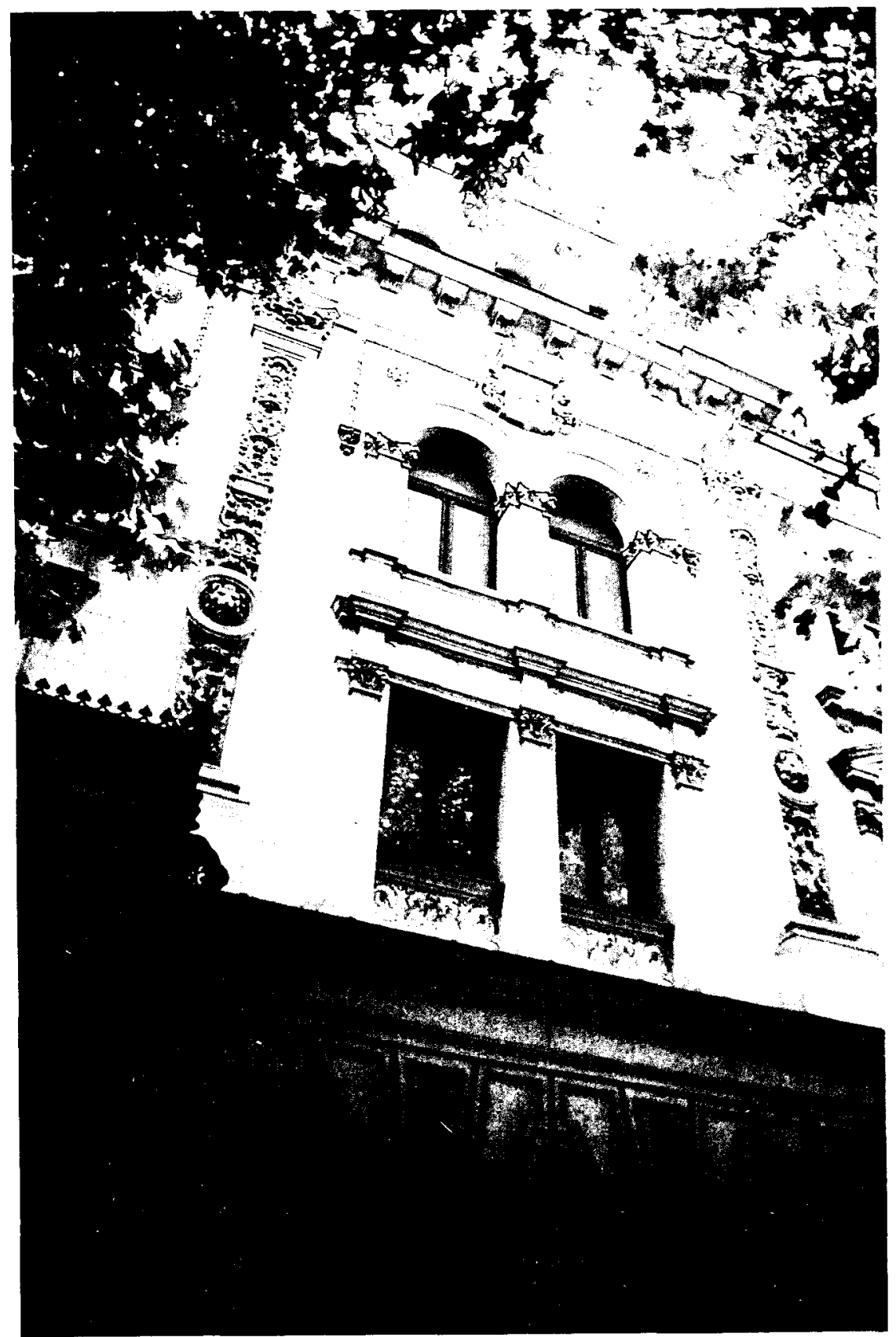

Fig. 11. Detalle de la ornamentación de la obra anterior. 
Construcción ${ }^{70}$. Mélida, conocedor de las virtudes de los nuevos materiales - gracias a los que había ganado admiración y distinciones-, propone un uso continuado de ellos, basando la renovación arquitectónica en la unión de estos con el ladrillo.

Pero lo que ahora nos interesa más es contrastar sus críticas a la ornamentación -que para él no es imprescindible ${ }^{71}$ y sus recomendaciones de laconismo decorativo ${ }^{72}$, con su propia obra, en la que no sólo no se desprende del ornamento, sino que ni siquiera transforma la imagen ecléctica, como haría Domènech i Montaner usando los mismos materiales (hierro, ladrillo, cerámica...) e iguales fuentes (mudéjar, gótico...).

Lo mismo va a ocurrir con el llamado "Estilo moderno", el cual se quiere oponer a la moda veleidosa del modernismo. Este supuesto nuevo estilo consiste, básicamente, en la unión de una construcción más funcional, realizada con materiales y técnicas avanzadas y un exterior ecléctico, en el que el ornamento sigue presente, denotando un estilo histórico e imprimiendo belleza. ${ }^{73}$

Sólo asi se puede entender que el edificio de la revista Blanco y Negro sea admirado como «... genuino ejemplar de la Arquitectura Moderna», apoyando tal calificación tanto en la solución de "las necesidades de la época" y la "actividad fabril", como en "la forma plateresca" - la manera en que «El arte moderno ha introducido alli ..., la Industria artística y el Arte ornamental» (7).

Es evidente que en este supuesto "Estilo moderno" no se prescinde en ningún caso de la ornamentación, antes al contrario, sigue siendo usada como argumento artístico. Otras muchas muestras apoyan esta idea, tales como los comentarios sobre la obra de Ortiz de Villajos, en los que casi se ignoran sus eficaces estructuras, ensalzando las apariencias ${ }^{74}$ o la necesidad de ornamentar los elementos metálicos, de forma que recuerden columnas con sus capiteles ${ }^{75}$.

70 MÉlida, A., Causas de la decadencia de la arquitectura y medios para su regeneración. Madrid 1899 (reprod. en $A$ y $C, 1900$, núm. 71, págs. 42 y ss. y núm. 74, págs. 87 y Ss.

1 MÉlidA, A., op. cit., pág. 12.

72 MÉlida, A., op. cit., pág. 21.

73 Cabello, L. M.", «Desde Madrid», A y C, 1899, núm. 51, págs. 101-102.

74 Repullés, E. M., «El arquitecto D. Agustín Ortiz de Villajos», $A$ y $C$, 1902, núm. 125, pág. 350.

75 En la sección de "Anuncios" del Anuario de la Asociación de Arquitectos de Cataluña abundan ejemplos de elementos de hierro para la construcción, casi siempre ornamentados. 


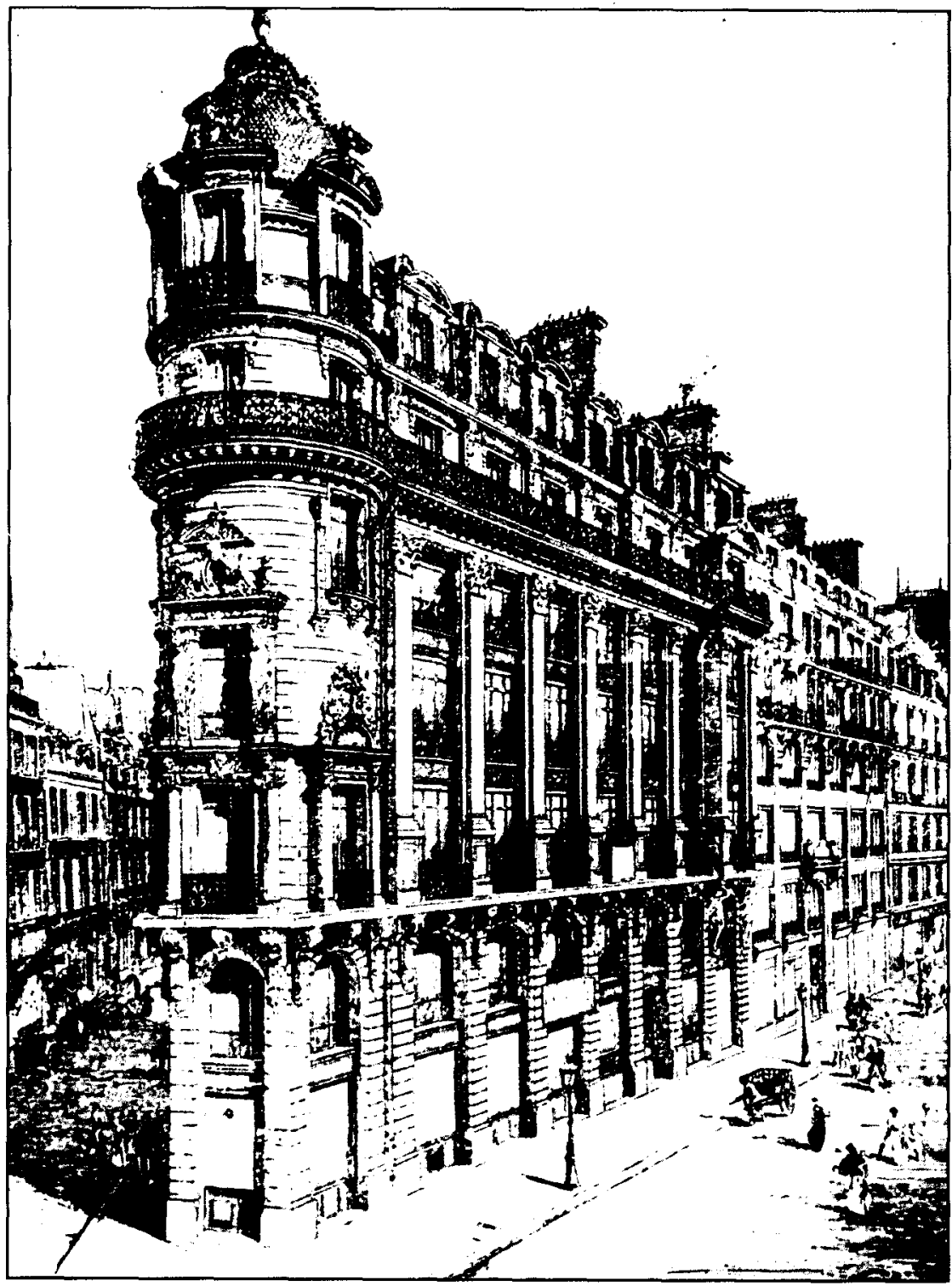

Fig. 12 Casa en la calle de Reaunour de París, reproducido en Arquitectura y Construcción, 1899, pág. 276. 
La arquitectura llegaría entonces a una postura semejante a la que aconteció en los orígenes del diseño industrial, a la que podríamos denominar como ultraornamentalista, ya que en ella la decoración del objeto no guarda relación alguna ni con su construcción - técnicamente más mecanizada - ni con su función - también más contemporánea-.

Algo así ocurre en la Exposición barcelonesa de 1929, cuyos espacios contenedores, de hierro y hormigón, fueron revestidos de un eclecticismo muy ornamental, estableciéndose una clara dialéctica con el «Pabellón Alemán" de Mies van der Rohe.

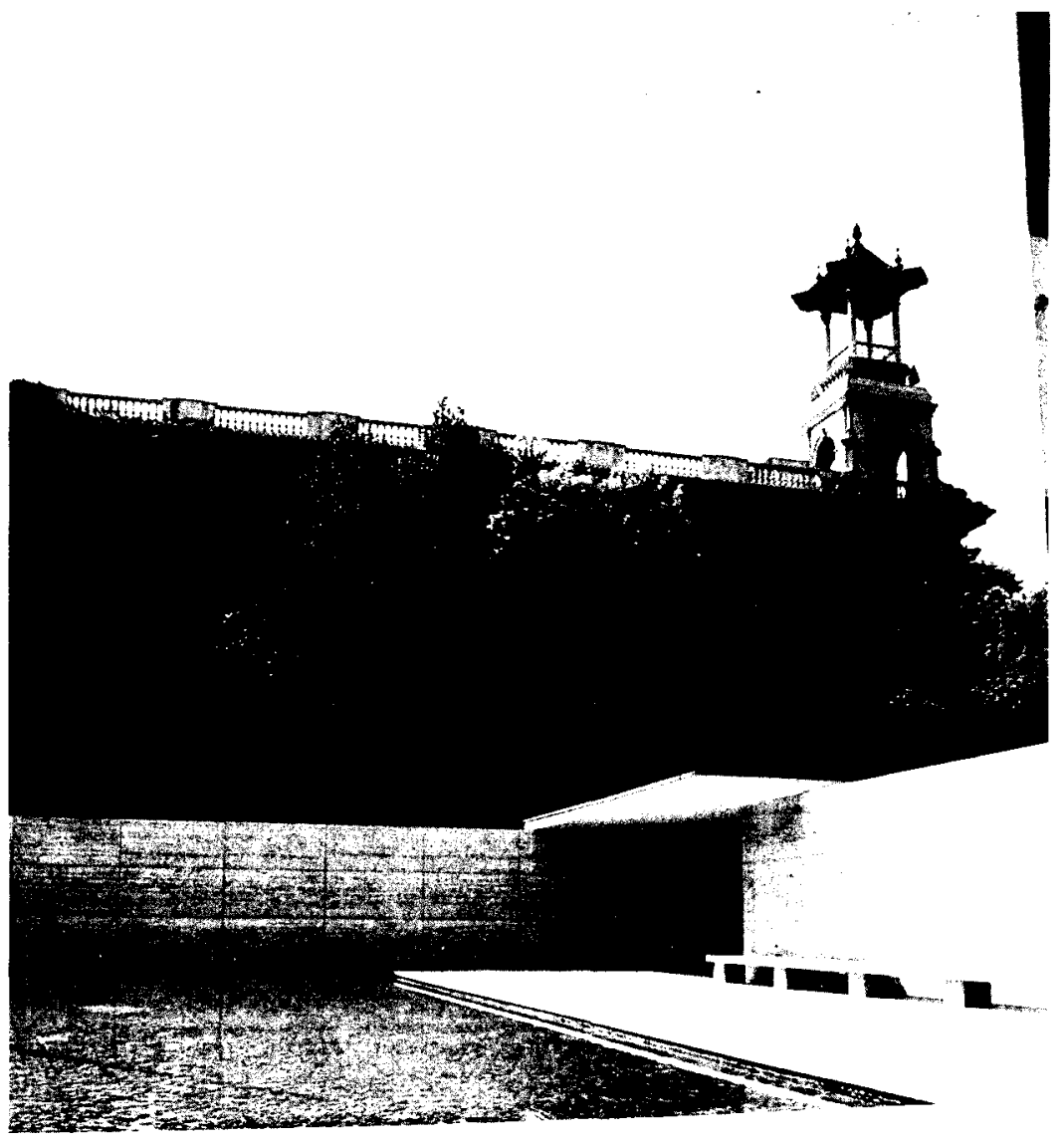

Fig. 13. Coexistencia de la ornamentación eclecticista y del Movimiento Moderno: en primer término el Pabellón Alemán de Mies van der Rohe, detrás el Palacio de la reina Victoria Eugenia. 
Regionalismo

El último intento de formular un modelo arquitectónico que fuera capaz de sobrevivir a la dispersión de fuerzas que aún se producía en la segunda década del siglo XX, siendo, al mismo tiempo, respetuoso con la herencia del pasado, fue el regionalismo.

Esta tendencia conecta su idea a la arquitectura con aquellas teorías políticas que pretendian la regeneración nacional desde la reafirmación de los valores tradicionales de la nación, en abierta oposición a la aplicación de soluciones extranjeras a los problemas locales. Por este motivo, cuando Manuel Vega aborda el tema, critica la contradicción de quienes pretenden "pregonar el regionalismo político y copiar ó imitar al mismo tiempo las formas artísticas de otros pueblos ó regiones" ${ }^{76}$.

Vicente Lampérez da la primera gran definición sobre el asunto ${ }^{77}$. Tras diferenciar claramente el tradicionalismo del exotismo, apostando, claro está, por el primero, propone como sistema para la consecución del tan anhelado nuevo estilo la adaptación o modernización de aquellos estilos nacionales que, en su opinión, están vivos.

Este tipo de planteamientos no deja de ser paradójico, ya que pretende superar el eclecticismo potenciando determinadas opciones históricas, lo que suponia en realidad una forma selectiva de aplicación de ese mismo eclecticismo, mediante la promoción de los estilos del pasado local.

Por lo tanto, el ornamento debe seguir encargándose de la caracterización de la arquitectura, ya que debe expresar los valores nacionales y locales que justificaban la implantación de este proyecto estilístico. Lampérez decía que «...la forma externa, es .... una manifestación del espíritu de la raza" ${ }^{78}$, dejando clara la responsabilidad que tendrá la ornamentación en esta corriente.

Anibal González, en su formulación del regionalismo sevillano, estimaba el cuidado de la decoración, hasta el mínimo detalle, tan imperativamente como la elección de los materiales o el diseño del trazado ${ }^{79}$.

76 VEGA, M., "Regeneración artística", $A$ y $C, 1901$, núm. 111, pág. 310.

$n$ LAMPEREZ, V., "La arquitectura española contemporánea. Tradicionalismos y exotismos", A y C, 1911, núm. 228, págs. 194-199.

78 Lamperez, V., op. cit., pág. 195.

79 GonzAlez, A., "Exposición Hispano-Americana de Sevilla para 1914", A y C, 1912, núm. 235, pág. 38. 


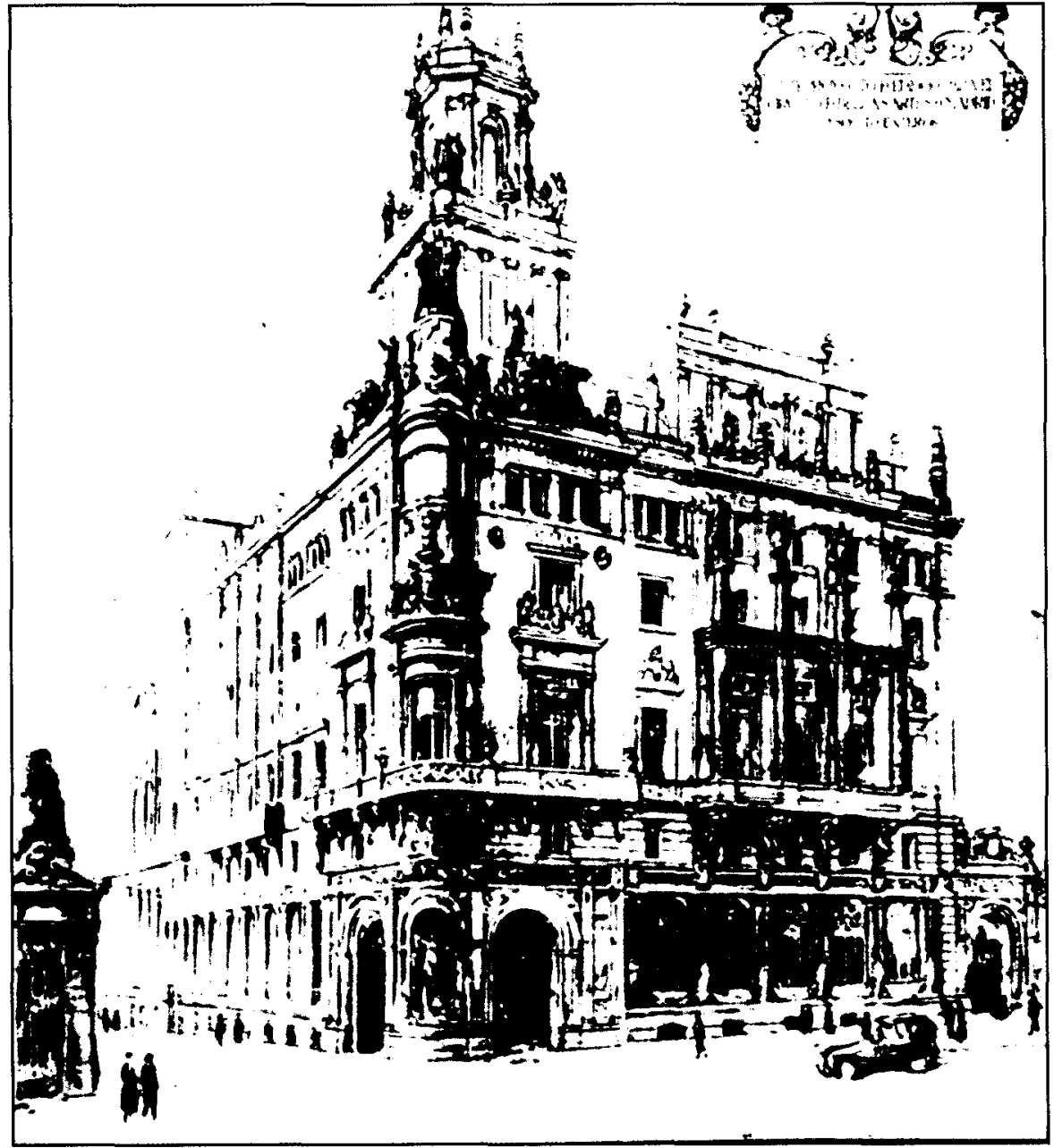

Fig. 14. Proyecto presentado por Manuel Vega, director de Arquitectura y Construcción al concurso para la sede del Circulo de Bellas Artes de Madrid, aparecido en la citada revista, año 1919, pág. 223.

Sin embargo, cuando Rucabado y él intentan la consagración definitiva del regionalismo, en el Congreso de Arquitectos de San Sebastián, su ponencia encuentra más resistencias de las previstas. Contra sus ideas se levantan las voces de quienes quieran desornamentar la arquitectura, como Demetrio Ribes -quien evolucionaba desde posturas "se- 
zesionistas" a otras más protorracionalistas-, y también Lampérez se desmarca de lo que considera una exageración de sus propósitos.

Las conclusiones al tema ${ }^{80}$, que intentan contentar a todos, admitiendo libertades y recomendando tradicionalismos - con lo que no satisfacen a nadie de lleno-, no cierran el debate.

Rucabado no entiende el distanciamiento de su maestro Lampérez y hace ante él una defensa a ultranza de lo ornamental, a través de Arquitectura y Construcción ${ }^{81}$. Partiendo de la base de que una cosa es la ingeniería y otra es la arquitectura, piensa que la ornamentación es independiente de cualquier problema técnico y la define como la «fundamental condición de «Bella Arte» ${ }^{82}$ que tiene la arquitectura, a partir de lo cual, opina que «...el ropaje arquitectónico, la nueva vestidura artística es de una importancia fundamental..." ${ }^{83}$.

Ante esta epidérmica devoción contraataca Ribes ${ }^{84}$, para quien es inexplicable tener por ideal arquitectónico la copia del pasado, y además, empeñar esa copia en lo más secundario.

La virulencia de este último debate quizás se debe a su emplazamiento cronológico. Era ya demasiado tarde para que el ornamentalismo sostuviese una arquitectura que pretendía pasar del respeto por la historia a una licitación activa en el futuro arquitectónico.

Y por lo que respecta a la incomprensión de Lampérez, se puede explicar con más facilidad invirtiendo los términos. Era éste quien tenía motivos para sentirse "traicionado" por un ornamentalismo basado en un eclecticismo tan intenso como el que emplea Rucabado en la "Casa Allende", resumen de todo el arte español, más próxima, desde luego al sincretismo radical de Domènech i Montaner que al orden académico y más hiriente, si cabe, al llegar con 20 años de retraso.

80 "VI Congreso Nacional de Arquitectos. Conclusiones. Tema V: "Orientaciones para el resurgimiento de una Arquitectura Nacional"", A y $C, 1915$, núm. 278, pág. 206.

81 RUCABADO, L., "La tradición en la arquitectura", $A$ y $C, 1917$, págs. 27-42. Rucabado escribe también sobre el tema un año antes en "Arquitectura española contemporánea", $A$ y C, 1916, núm. 282, págs. 1-8.

32 RUCABADO, L., "La tradición en la arquitectura»..., pág. 31.

83 RUCABADO, L., op. cit., pág. 32.

${ }^{84}$ RiBes, D., "Orientaciones para el resurgimiento de una Arquitectura Nacional. Trabajo leido por el señor Ribes", $A$ y $C, 1918$, págs. 21-25 y "La tradición en la arquitectura", A y $C, 1918$, págs. 21-28. 


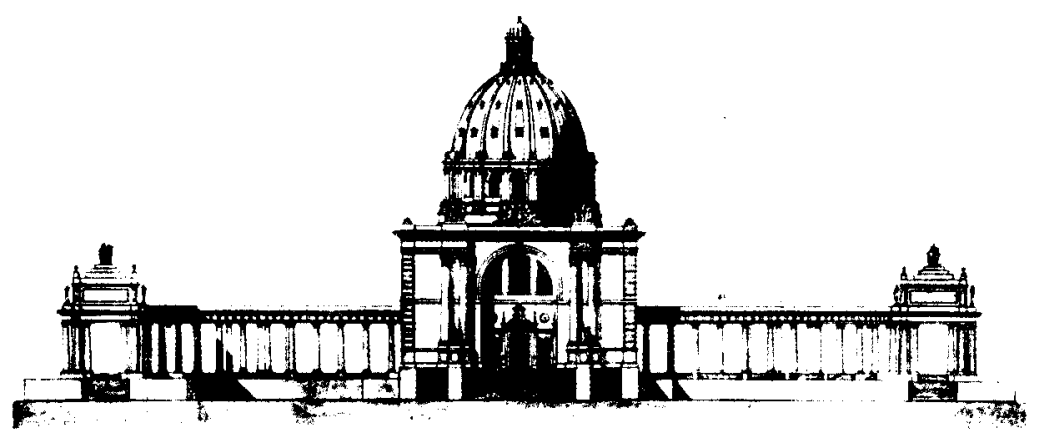

Fig. 15. Un ejemplo de la longevidad de los modelos históricos en la enseñanza de la arquitectura: Proyecto de monumento a la marina de guerra catalana, realizado en la Escuela Superior de Arquitectura de Barcelona y reproducido en Arquitectura y Construcción el año 1919.

\section{Desornamentación}

Aunque de manera escasa, esporádica y casi marginal, es posible detectar también en Arquitectura y Construcción otra actitud frente a la ornamentación. Se trata de aquella que más que teorizar sobre cuándo, cómo y dónde debe emplearse el ornamento, terminará por cuestionar la propia existencia del mismo.

La desnudez ornamental irá siendo sugerida en comentarios aislados, ajenos a las firmas habituales, en los que irá casi siempre unida a la problemática de los nuevos materiales, la industrialización, etc. Y, a pesar de que este tipo de manifestaciones resulta reducido en número, tiene la importancia de su excepcionalidad, dando contrapunto a la idea de artisticidad que prodomina por encima de la de funcionalidad, incluso en la tercera década del siglo.

Esa importancia se comprenderá aún mejor a la luz de ejemplos como la viva polémica que mantienen Vega y Repullés en varios núme- 
El debate en torno al ornamento arquitectónico en la revista ...

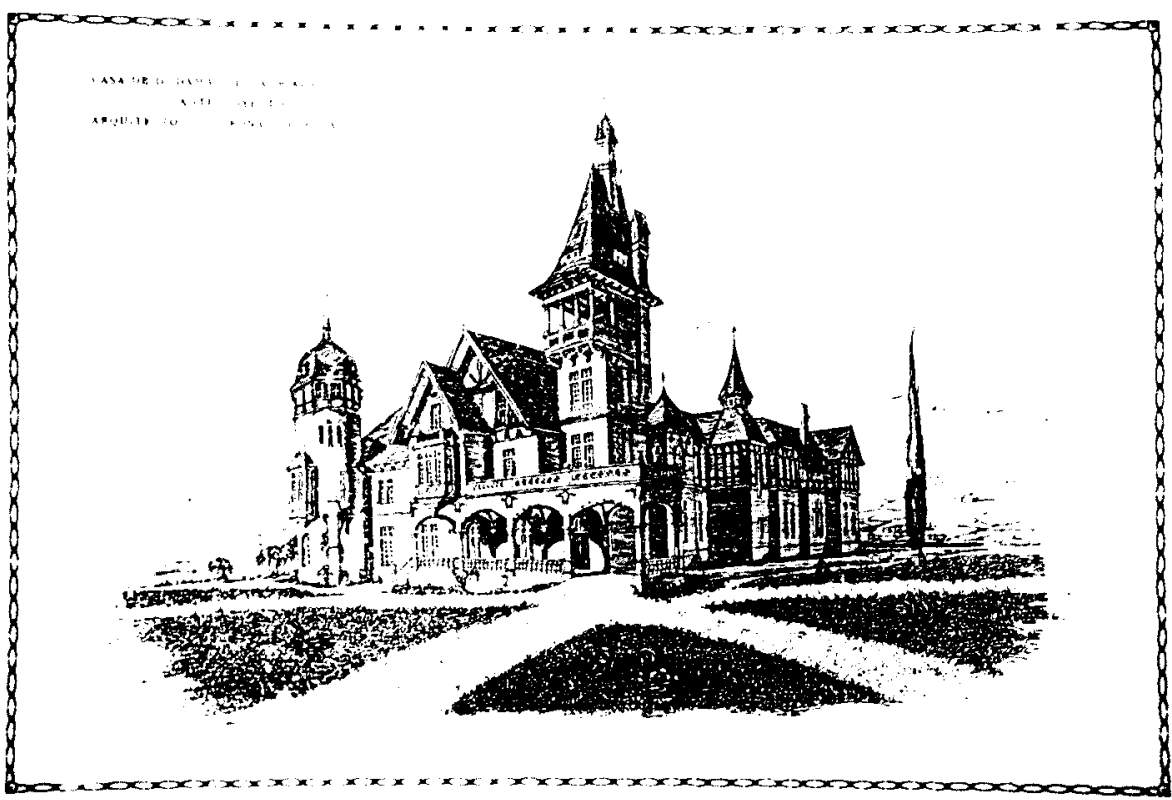

Fig. 16 Proyecto de Leonardo Rucabado aparecido en el año 1916 en Arquitectura y Construcción.

ros de la revista ${ }^{85}$, sólo por el hecho de que el segundo -poco dudoso de querer acabar con la concepción tradicional de la arquitectura- se manifieste partidario de que el arquitecto sea un experto en el uso de los nuevos materiales.

Tal pretensión perjudica, según Vega, las dotes artísticas del arquitecto, acarreando el peligro de "dotar a sus construcciones de un marcado carácter industrial, práctico, vulgar» ${ }^{86}$, proponiendo la alternativa contraria: «Hagamos arte, que ya los prácticos, los contratistas, los ingenieros, los industriales, nos darán el material que lo perpetúe, sin que nosotros debamos preocuparnos por ello" ${ }^{87}$.

${ }_{85}$ Vega, M., “Actualidades", A y $C, 1904$, núm. 148, págs. 324-325. Repullés, E. M., "Actualidades", $A$ y $C, 1905$, núm. 150, págs. 2-4. VEGA, M., "El arquitecto-artista", $A$ y $C$, 1905, núm. 151, pág. 49. Repulles E. M., "Actualidades", A y $C, 1905$, núm. 154, pág. 131.

${ }^{86}$ VEGA, M., "Actualidades", $A$ y $C, 1904$, núm. 148, pág. 324.

87 VEGA, M., op. cit., pág. 325. 


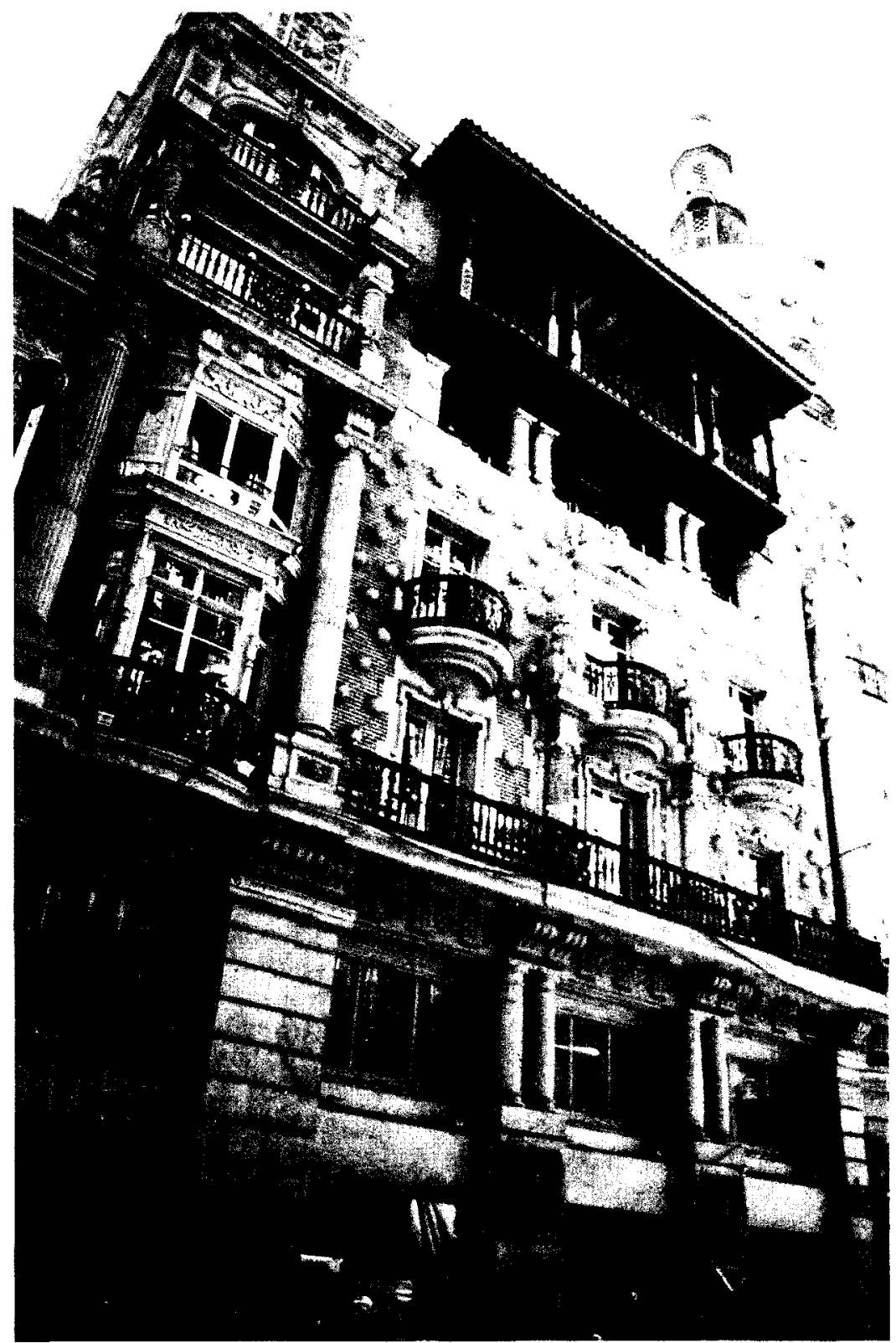

Fig. 17 Leonardo Rucabado: Casa Allende, edificio recogido en Arquitectura y Construcción, en su anuario de los años 1920-21. 
Frente a esto, no pueden dejar de sorprender afirmaciones como las que hace el francés Jourdain, al pedir «que la belleza se haga sinónima de la bondad" ${ }^{88}$, en clara alusión a la primacía de la función sobre la forma, antes de negar "la aborrecible y egoista doctrina que pretende que lo útil destruye lo bello" ${ }^{89}$, finalizando con una recomendación para que la belleza deje de ser juzgada por las aplicaciones ornamentales.

Ahora bien, no podemos olvidar que esas manifestaciones son hechas por un autor extranjero en una revista también foránea. Por ello, es lícito preguntarse si tienen alguna importancia en la arquitectura española.

Pero, para que no falte representación de tendencia alguna, aparece también en Arquitectura y Construcción un testimonio todavia más abiertamente protorracionalista, efectuado por un español, Teodoro de Anasagasti, en el que denomina a las fábricas como "Las primera y más típicas manifestaciones de la arquitectura moderna» ${ }^{90}$, poniendo como ejemplo la más conocida obra de Behrens.

Anasagasti ensalza el vapor, el humo, las llamaradas de las máquinas, "seres férreos vivientes" "1, tanto como critica la costumbre de acicalar los espacios fabriles con revestimientos historicistas, y resume su propia evolución en Alemania — donde firma el artículo- de la siguiente manera: «...vinimos a estudiar el arte puro; y hemos terminado por hacernos industriales, sintiendo las excelencias de este arte sencillo y nuevo" ${ }^{92}$.

Cuando estos pensamientos se generalicen, desplazando la disciplina arquitectónica al terreno ingenieril y sustituyendo su significado artístico por otros como la maquinización, el progreso, la funcionalidad absoluta, etc., la antigua importancia del ornamento habrá de operar en su contra, al quedar identificado con todo aquello que se pretende superar. La supresión del ornamento equivaldrá a la eliminación de los pensamientos y sensaciones que él se había encargado de evocar.

Pero no pensemos que esto ocurrió rápida y continuadamente. Vale la pena recordar que un año después de los comentarios de Anasagasti,

86 Jourdain, F., "La arquitectura de mañana", A y C, 1908, núm. 186, pág. 22.

Bo Ibidem.

${ }^{\circ}$ AnASAgasti, T., “El arte en las construcciones industriales", $A$ y $C, 1914$, núm. 264, pág. 150.

91 Anasagasti, T., op. cit., pág. 152.

92 ANASAgasti, T., op. cit., pág. 155. 


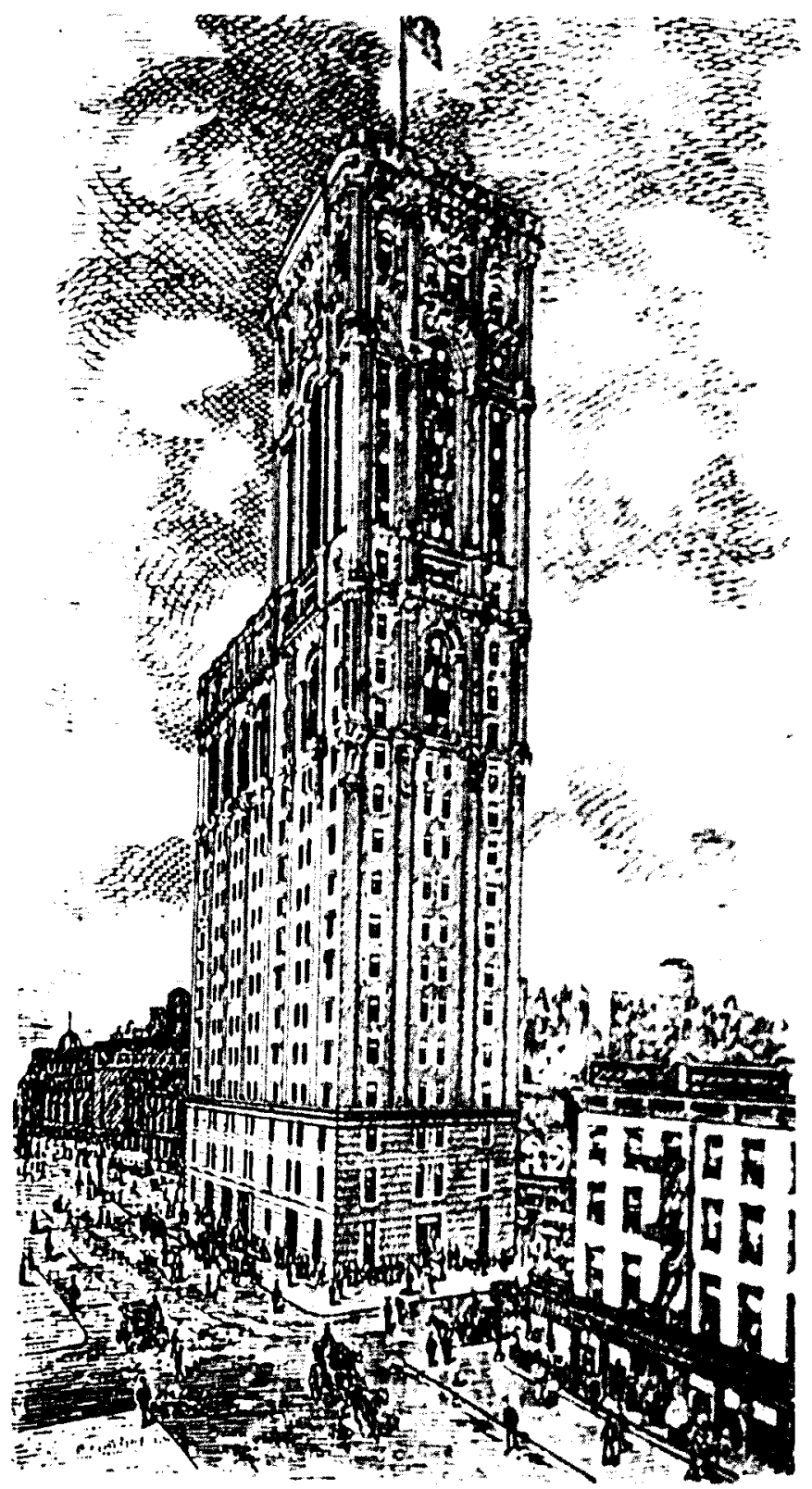

Fig. 18 La ornamentación continuaba recubriendo rascacielos como los que se reprodujeron en Arquitectura y Construcción en el año 1905. 
se alaban los azulejos y frontones colocados en una fábrica, calificándola como "grupo notable de edificaciones clásico-modernas" ${ }^{93}$.

La desaparición del ornamento y el trasvase de la arquitectura más aliá de las Bellas Artes tardarán aún en generalizarse en España, demasiado para que los contemplen las páginas de Arquitectura y Construcción.

${ }^{23}$ Pollés, S., “Edificio para los almacenes El Águila», $A$ y $C, 1915$, núm. 270 , págs. 4-6. 
